\title{
TAPICES Y CRÓNICA, IMAGEN Y TEXTO: UN ENTRAMADO PERSUASIVO AL SERVICIO DE LA IMAGEN DE CARLOS V
}

Antonio Gozalbo

Universitat Jaume I

Resumen: Las consecuencias artísticas de la conquista de Túnez por Carlos V (1535) resultaron fundamentales para la articulación plena de su imagen de poder. Dentro de este amplio conjunto de manifestaciones plásticas y literarias destaca la monumental serie de tapices de «La Jornada de Túnez». Con el presente artículo queremos aportar mayor claridad a la tesis que otorga la autoría intelectual del conjunto al cronista Alonso de Santa Cruz, mostrando los evidentes vínculos entre los paños y su Crónica del Emperador Carlos V. Así pues, tapices y crónica confluyeron generando un potente entramado icónico-literario destinado a la mitificación de Carlos V.

Palabras clave: Carlos V, imagen de poder, tapices de «la Jornada de Túnez», Alonso de Santa Cruz, Crónica del Emperador Carlos V.

ABSTRACT: The artistic consequences of the conquest of Tunis by Charles V (1535) were essential in the full articulation of its image of power. Within this broad set of visual and literary artistic expressions the monumental series of tapestries of «la Jornada de Túnez» are highlighted. In this article we want to throw light upon the thesis of intellectual authorship of the whole work attributed to the chronicler Alonso de Santa Cruz, showing the obvious links between tapestries and his Chronicle of Emperor Charles $V$. Thus, tapestries and chronicle converged generating a powerful iconic literary framework intended to mythicize Charles V.

Keywords: Charles V, image of power, tapestries of «la Jornada de Túnez», Alonso de Santa Cruz, Crónica del Emperador Carlos V. 
«Colgarían a Augusto tapicería en que estuviese figurada la victoria que tuvo de los Britanos; al modo que el Emperador Carlos V hizo figurar en su tapicería la jornada de Túnez y Barbarroja». ${ }^{1}$ Esta cita, tomada de los Comentarios de la pintura que Felipe de Guevara escribió hacia 1560, es muestra clara de la importancia que la serie de tapices destinados a celebrar y recordar la conquista de Túnez tuvo en la configuración de la imagen de poder de Carlos V. La razón que llevó al encargo de este majestuoso conjunto textil fue la conmemoración de la triunfal campaña militar que el emperador encabezó en 1535, operación que conquistó la ciudad norteafricana. Sus limitados efectos políticos y militares no impidieron que la acción bélica fuese aprovechada por la propaganda carolina, por lo que se celebraron grandes entradas triunfales en Italia al tiempo que se realizaban hojas volantes, grabados conmemorativos, orfebrería... Aunque tejida quince años después, la pieza más significativa de este entramado conmemorativo fue la serie de tapices de la «Jornada de Túnez», el encargo más importante, costoso y monumental en el campo de las artes visuales que nunca hiciera la corte de Carlos V. ${ }^{2}$

De forma coincidente fue fraguando un importante conjunto de producciones escritas, ${ }^{3}$ entre las que ocupan un papel central los textos de los

1. Felipe de Guevara: Comentarios de la pintura, ed. con discurso preliminar y notas de Antonio Ponz, Ortega, Madrid, 1788.

2. Los efectos artísticos y los tapices fruto de la campaña tunecina han propiciado la aparición de numerosos estudios, destacando los debidos a Fernando Checa Cremades: Carlos V. La imagen del poder en el Renacimiento, El Viso, Madrid, 1999; Tesoros de la corona de España. Tapices flamencos en el Siglo de Oro, Fonds Mercator-Sociedad Estatal para la Acción Cultural en el Exterior, Madrid, 2010; «Imágenes de otros mundos: turcos y moros en varias series de tapices de la Alta Edad Moderna», en V. Mínguez y I. Rodríguez (coord.): Arte en los confines del Imperio. Visiones hispánicas de otros mundos, Universitat Jaume I, Castellón, 2011, pp. 27-50; Miguel Ángel de Bunes Ibarra y M. Falomir Faus: «Carlos V, Vermeyen y la conquista de Túnez», en J. L. Castellano y F. Sánchez Montes (eds.): Carlos V. Europeísmo y universalidad, Sociedad Estatal para las Conmemoraciones de los Centenarios de Felipe II y Carlos V, Madrid, vol. 5, 2001, pp. 243-257; Miguel Ángel De Bunes IbArRA: «Vermeyen y los tapices de la conquista de Túnez. Historia y representación», en BERNARdo GARCía (ed.): La imagen de la guerra en el arte de los antiguos Países Bajos, Universidad Complutense-Fundación Carlos de Amberes, Madrid, 2006; «Las empresas africanas de las monarquías ibéricas en las tapicerías reales», en F. CHeca (coord.): Los triunfos de Aracne. Tapices flamencos de los Austrias en el Renacimiento, Fundación Carlos de Amberes, Madrid, 2011, pp. 224-251; Sylvie Deswarte-Rosa: «L'expédition de Tunis (1535): Images, interprétations, répercussions culturelles», en B. BENASSAR y R. SAUZET (coords.): Chrétiens et Musulmans à la Renaissance, Honoré Champion Editeur, París, 1998, pp. 75-132; José Luís GonzÁLEZ GARCía: «Pinturas tejidas. La guerra como arte y el arte de la guerra en torno a la empresa de Túnez», Reales Sitios, vol. Xliv, n. 17 (2007), pp. 24-47; Hendrik J. Horn: Jan Cornelisz Vermeyen, Painter of Charles $V$ and His Conquest of Tunis: Paintings, Etchings, Drawings, Cartoons and Tapestries, 2 vols., Davaco, Doornspijk, 1989; George Kugler (coord.): Kaiser Karl V. erobert Tunis., Kunsthistorisches Museum, Viena, 2013; W. Seipel y G: Kugler: Der Kriegszug Kaiser Karls V. gegen Tunis. Kartons und Tapisserien, Skira, Viena, 2000; Georg VoIgt: Die Geschichtschreibungüber den Zug Karl's V. gegen Tunis (1535), Leipzig, 1872.

3. VoIGT, Die Geschichtschreibung. 
principales cronistas. ${ }^{4}$ Así pues, Carlos V, al igual que César en sus campañas, ${ }^{5}$ fue acompañado por artistas y escritores destinados a dejar constancia de la acción bélica, creando con sus obras un potente entramado laudatorio.

\section{Alonso de Santa Cruz y su papel como cronista}

Generalmente es admitido que fue Alonso de Santa Cruz (Sevilla, 15051567) el cronista que mayor influencia tuvo sobre los tapices y sus cartelas. ${ }^{6}$ Tras ser nombrado cosmógrafo de la Casa de Contratación, a partir de 1537 iba a establecer una relación muy fluída con Carlos V. La satisfacción del monarca con su compañía propició que se convirtiera en hombre de confianza, nombrándolo caballero de la Casa Real y cosmógrafo mayor. Los últimos años de la década de 1540 e inicios de 1550, en paralelo con el gran proyecto de los tapices tunecinos (1548-1554), coincide con uno de los momentos de mayor relación entre ellos. Así, Santa Cruz se vio forzado a rechazar la invitación a participar como jurado en un examen para pilotos por «estar muy ocupado en hacer ciertas obras que Su Majestad le ha mandado». Incluso en una de sus misivas, fechada entre 1551-1553, repasa algunos de estos trabajos: cartas, mapas, una traducción de Aristóteles, la Crónica de los Reyes Católicos y la del mismo emperador... ${ }^{7}$ Realmente no existe documentación conocida que pruebe la relación entre su Crónica del Emperador Carlos $V^{8}$ y los tapices. No obstante, como vamos a intentar demostrar a continuación, un análisis conjunto y en profundidad de texto e imagen así parece evidenciarlo.

4. Cabe destacar los escritos, autónomos o incluidos en obras mayores, del licenciado Arcos, Alonso de Santa Cruz, Juan Ginés de Sepúlveda, Francisco López de Gómara, Gonzalo de Illescas, Martín García de Cereceda, Alonso de Sanabria, León el Africano, Mármol Carvajal, Pedro Girón, Luís de Ávila, J. A. de Vera y Zúñiga, Francisco de Ferrera, Martínez Montaner, Pedro Mexía, Pedro de Salazar o Calvete de la Estrella, además de otros relatos anónimos. También aparecieron numerosas relaciones, como la de Diego Hurtado de Mendoza, además de recopilaciones y publicaciones en francés, alemán, etc.: es el caso de los escritos de Antoine de Perrenin, J. Etrobius, J. Bellerus, el Caballero d'Herbays, G. Paradin, G. Montouché, etc.

5. Horn, Jan Cornelisz.

6. Checa, Carlos V Tesoros; De Bunes, «Vermeyen»; Deswarte-Rosa, «L'expédition»; GonzÁlez, «Pinturas tejidas»; Horn, Jan Cornelisz.

7. Ángel Arribas Lázaro: «Unas cartas de Alonso de Santa Cruz», Asclepio, $26-27$ (1974-5), pp. 257-266; Juan de Mata Carriazo (edición y estudio crítico): Alonso de Santa Cruz. Crónica de los Reyes Católicos, 2 vol., Publicaciones de la Escuela de Estudios Hispanoamericanos, Sevilla, 1951; MARIANO Esteban Piñeiro: «El Emperador y la Astronomía. El Astronómico Real del matemático sevillano Alonso de Santa Cruz», en vv. AA.: El Emperador Carlos Vy su tiempo. IX Jornadas Nacionales de Historia Militar, Demos, Madrid, 2000, p. 689-697; J. B. VILAR: Mapas, planos y fortificaciones hispánicas de Túnez (s. XVIXIX), Universidad de Murcia, Murcia, 1991.

8. Alonso de Santa Cruz: Crónica del Emperador Carlos V, 5 vols., Blázquez y Beltrán, Madrid, 1922-1925. 
TAPICES Y CRÓNICA, IMAGEN Y TEXTO:

Un entramado Persuasivo al Servicio de la imagen de CARLOS V

«El mapa» o vista cartográfica

El primer tapiz de la serie es una monumental vista del Mediterráneo occidental, realizada con un verismo absoluto [Fig. 1]. Este realismo geográfico se debe, en gran parte, a la figura del cosmógrafo Alonso de Santa Cruz, y a la más que probable influencia que tuvo en la serie. Se sabe que Carlos V le encargó una carta geográfica del espacio en que iba a desarrollarse la campaña bélica, hoy desaparecida. El mismo interés por determinar el espacio de la acción se destila de los tapices, que cuentan incluso con cartelas de orientación, y de su crónica, en cuyo texto se trata con especial detallismo las rutas marítimas, los principales accidentes, la cantidad de población de determinadas urbes, etc. Además, el carácter realista y narrativo de los tapices se complementa en toda la serie con la inclusión de cartelas explicativas, destinadas a reforzar la imagen de hecho real, no exaltación fabulosa.

En este caso concreto, la primera cartela se encuentra en la parte superior, como inscripción en el entablamento fingido, siendo su objetivo realizar una justificación de la campaña. ${ }^{9}$ Además de otra cartela en latín, una tercera inscripción aparece en una tabla sostenida por el mismo Vermeyen: en ella se recoge una auténtica declaración de principios en defensa del rigor científico, anteponiendo los valores del realismo cartográfico y la narrativa histórica a la belleza artística. ${ }^{10}$ Tal como refiere la cartela, las crónicas escritas en paralelo

9. «Haviendo Bairedin Barbaroxa Capitan general de mar de Solimano príncipe de los Turcos con una armada de ciento XX galeras hecho mucho daño en algunas costas de Christianos: ocupo el reyno de Tunez haziendose pacifico y absoluto señor del / y de otra gran parte de Aphrica con tan grave y euidente peligro de lo mas de la Christiandad que fue necesario que el Emperador Carlos V Rey de España se opussiese a estas nueuas fuerças y por su persona dyese orden a tan gran expedición, y deter / minado en la prosecucion dello ordeno que la armada que el Rey de portugal su cuñado mando hacer en Lisbona de carauelas y otros navios con su Capitan Antonio de saldaña uiniese en Barcelona como a lugar mas apto a esta embarcacion. Mando venyr ally al mismo / tiempo Marques de Mondejar con el armada hecha en Malaga en que uenian nueue mill Españoles y las galeras de España. El principe doria partiendo de genova con diez y seis galeras suyas llego a Barcelona despues de hauer ordenado las otras armadas que se hauian / hecho en Italia y el Marques del gasto con cargo que tenya de su Md de recoger las: tenyendo en ellas seis mil alemanes quatro mil españoles soldados viejos cinco mil Italianos: tocando en Napoles y Sicilia llego en la Isla de Cerdeña cerca del cabo pola donde espero la llegada del emperador». En W. Seipel y G. Kugler, Der Kriegszug.

10. «Cuenta de leguas / Cuenta de mllas / Porque la conquista que Carlos Emperador de / Romanos quinto deste nombre y primero entre / los Reyes de España: hizo en Africa el año M / DXXXV. tuuo causas grandes y de mucha necessi / dad. Las quales los Cronistas de su tiempo decla / ran mas copiosamente en sus historias. Aquellas / dexadas aparte; solo se figura en esta obra la se / miança del hecho quanto mas al propio fue pos: / sible. Y porque para bien entenderlo conuiene te / ner noticia de / las regiones y provincias en que los / negocios pasaron y donde los aparejos se proueyeron: / en este paño se tratara dello tan al natural que ni / nguna cosa tocante a la cosmografia se pueda dessear / assi en las Costas de Africa como en las de Europa / y sus fronteras: / declarando las formas dellas con sus puertos principales paios: islas: uientos: en las mis / mas distancias que se hallan: teniendo mucho / mas restero a la precisión de su asiento que a la / propiedad de la pintura. Y assi como esto se ha hecho en lo de la mar conforme a la cosmografia / assi en lo della tierra el pintor a observadolo que / a su arte se deue. Considerando el que lo mira / re que lo 


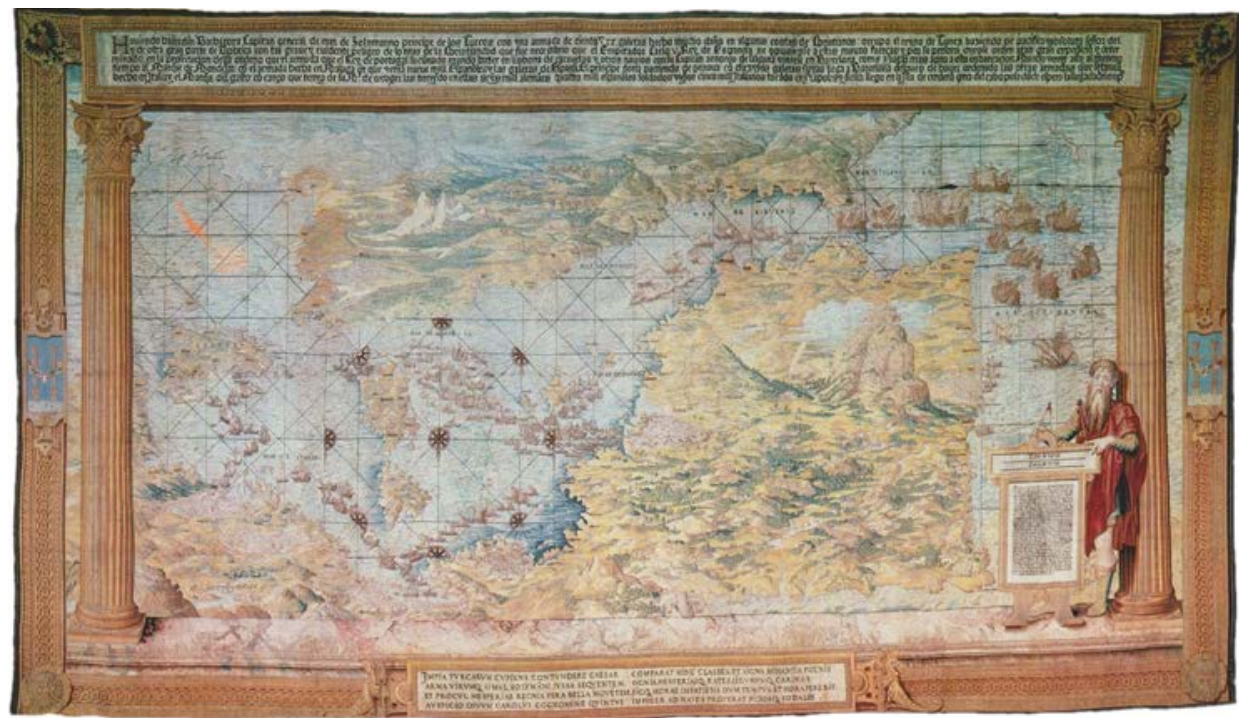

Fig. 1. Jan Cornelisz Vermeyen (diseño) y Willem de Pannemaker (realización), «El mapa» o Vista cartográfica, Bruselas, 1548-1554, $523 \times 884 \mathrm{~cm}$. Madrid, Patrimonio Nacional. PN Inv.-Nr. A230-6289, S.13/1 (original)

«declaran más copiosamente en sus historias» los antecedentes del conflicto. Prácticamente todas ellas hacen referencia a la historia de los hermanos Barbarroja y al ascenso de Hayreddin a almirante de Solimán el Magnífico. Acabó estableciendo un auténtico reino pirata en Túnez, nido para otros corsarios, ${ }^{11}$ al tiempo que se hacía con el control de otros enclaves de la zona.

La presencia de Barbarroja en la ciudad norteafricana ponía en jaque el control español del Mediterráneo occidental, y más teniendo en cuenta, tal y como afirman Cereceda y Santa Cruz, la evidente alianza que el pirata había establecido con el soberano francés Francisco I. ${ }^{12} \mathrm{El}$ mismo Carlos V se puso, por tanto, al mando de toda la compleja operación, «por manera que $\mathrm{Su}$ Majestad en todos estos días no se ocupaba sino en mandar proveer las cosas necesarias para su camino». ${ }^{13}$

uee desde Barcelona donde se comen: / ço la nauegacion para Tunez. La qual es entre / leuante y mediodia: dexando el Norte detras / sobrel hombro yzquiedo, pues fundados / en esta uerdad: se pueden despues mejor / entender las particularidades de los otros / tapizes y el sitio de aquellas de pas / so lo que en ellos se contiene». En W. Seipel y G. Kugler, Der Kriegszug.

11. «Le vinieron a dar obediencia con sus armadas Sinan de Areje, turco al que llamaban el Judio, y Cachidiablo y Tuchimani, todos turcos y grandes corsarios». SANTA Cruz, Crónica, p. 203.

12. MARTín GARCía DE CERECEDA: Tratado de las campañas y otros acontecimientos de los ejércitos del Emperador Carlos Ven Italia, Francia, Austria, Berbería y Grecia, Sociedad de Bibliófilos Españoles, 1874 y Santa Cruz, Crónica, p. 237: «ayuda del Rey de Francia, el cual tenía hecha paz y liga con el Gran Turco».

13. Santa Cruz, Crónica, pp. 238-239. 


\section{La revista de las tropas en Barcelona}

El objetivo de este segundo paño es mostrar todo el poder y magnificencia del ejército imperial [Fig. 2]. Tras reunir una imponente fuerza militar en Barcelona, el emperador convocó a todo su ejército para organizar una gran parada militar en el Campo de la Laguna, cerca de la Puerta de Perpiñán. Dicho tema es uno de los datos que nos permiten vincular de forma clara el conjunto de tapices con Santa Cruz, ya que es el único cronista que le da importancia en su texto. De hecho, dedica dos capítulos enteros a los distintos ceremoniales realizados en Barcelona. Al fondo de la imagen podemos contemplar la magnificencia de la flota reunida. Santa Cruz relata la aparición el 28 de abril de los navíos del infante don Luis de Portugal, ${ }^{14}$ recibidos con gran pompa. ${ }^{15}$ Ritual similar es el que siguió Andrea Doria, describiendo igualmente la crónica el complejo ceremonial caballeresco de homenaje y bienvenida.

En general, las crónicas no otorgan relevancia a estos hechos: Illescas ni la menciona; Cereceda y Gomara ${ }^{16}$ hacen una somera referencia. Así pues, solo Santa Cruz le presta una atención equivalente en su escrito, dedicando a la parada un capítulo entero. ${ }^{17}$ Explica cómo los principales capitanes dudaron del destino de la expedición y de quién debía ser el general que la dirigiese. El cardenal Sigüenza y Francisco de los Cobos fueron enviados como representantes para hablar con Carlos V, quien «sin darles respuesta alguna mandó que otro día, 14 de mayo, se armasen los grandes caballeros cortesanos de su casa y corte, porque quería hacer reseña de ellos y de su gente». Una vez reunidas las tropas a las cuatro de la mañana, el emperador se dirigió a ellas afirmando que Cristo era su capitán, y debían desfilar ante él en homenaje. ${ }^{18}$ Precisamente ese desfile ante el emperador, flanqueado por un gran estandarte, es el que se reproduce en el tapiz. Así pues, tanto la crónica, la imagen y la cartela ${ }^{19}$ coinciden en incidir en aspectos representativos y áulicos:

14. «23 carabelas y dos muy buenas naos y un galeón tan grande que puso admiración á todos porque traía 36 tiros gruesos por banda, con otros muchos pequeños de que no se hacía cuenta, y asi mismo todas las carabelas y naos venían muy bien aderezadas». SAnTa Cruz, Crónica, p. 239.

15. «como supieron que Su Majestad estaba a una ventana para verlos, alzaron todos velas, y en soltando una pieza de artillería la capitana alzaron todos en orden muchas banderas y estandartes, y de esta manera llegaron a donde habían de surgir y soltaron cada carabela por sí la artillería que traía para que se viese la mucha que traía». Santa Cruz, Crónica, p. 250.

16. Francisco López de Gomara: Las guerras de mar del Emperador Carlos $V$, ed. de M. A. De Bunes y N. Jiménez, Sociedad Estatal para la Conmemoración de los Centenarios de Felipe II y Carlos V, Madrid, 2000; y Gonzalo de Illescas: Jornada de Carlos V a Túnez, Biblioteca de Autores Españoles, Madrid, 1946.

17. «De la reseña que el Emperador mandó hacer de los grandes y caballeros de su Casa y Corte, y los aderezos que algunos sacaron, y de los Señores Prelados, Embajadores y flamencos e italianos que fueron con Su Majestad en la jornada». SAnta Cruz, Crónica, pp. 257-261.

18. Ante la duda de «Quien había de ser su Capitán General, que él (Carlos V) se lo mostraría, y a la hora mandó desplegar sus banderas y estandartes y les mostró un rico y devoto crucifijo que en él estaba figurado, y les dijo que aquel había de ser su Capitán General, y que a si (a Carlos V) habían de obedecer por su alférez, y así mandó que delante de él pasase cada grande con sus continuos» SANTa Cruz, Crónica, p. 260.

19. «Todas estas cosas asy ordenadas y medido el tiempo conforme a lo que el Emperador le parecia que convenia partyr para Barcelona: a la misma raçon que las / armadas podrian llegar: parte de Madrid y llega 


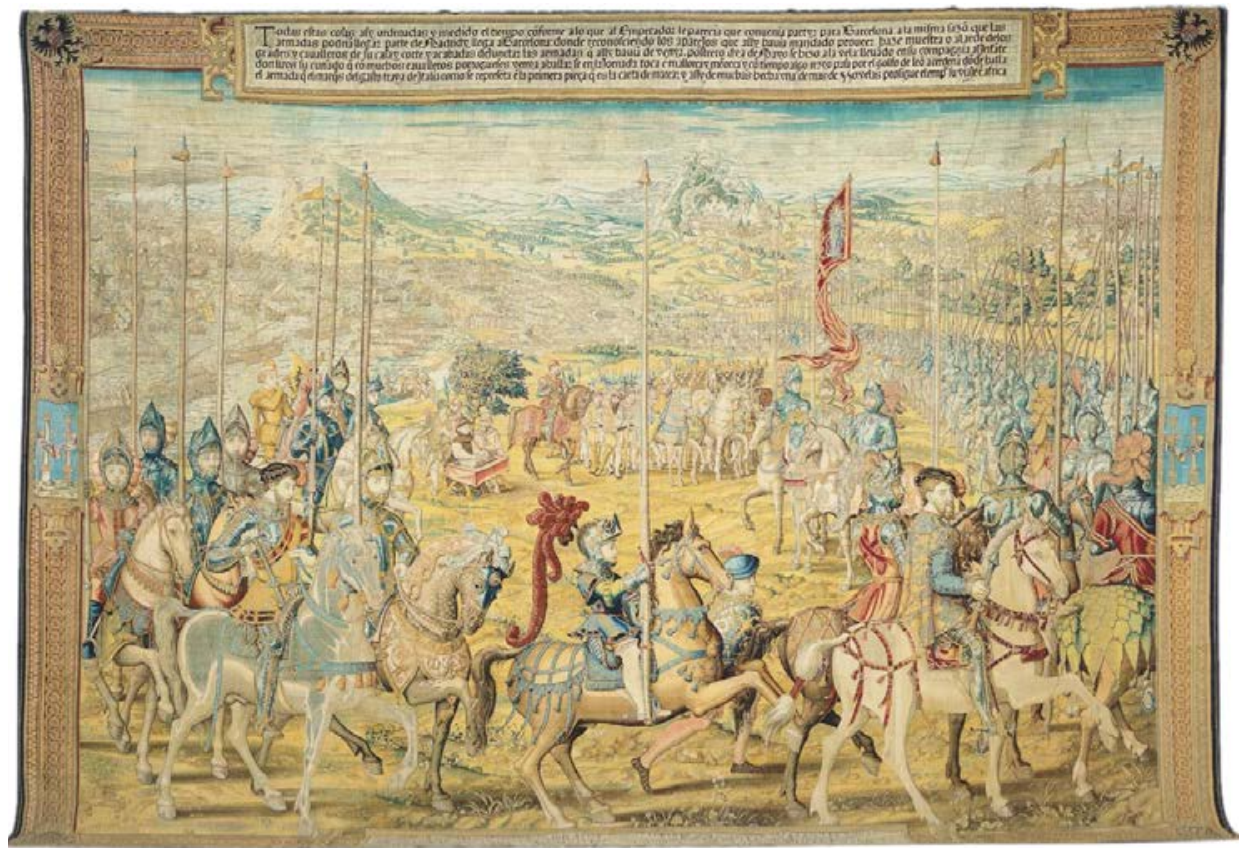

Fig. 2. Jan Cornelisz Vermeyen (diseño) y Willem de Pannemaker (realización), La revista de las tropas en Barcelona, Bruselas, 1548-1554, $532 \times 715 \mathrm{~cm}$. Madrid, Patrimonio Nacional. PN Inv.-Nr. A325-10761, S.13/2 (original)

el despliegue de ambas partes del ejército, armada al fondo y ejército de tierra en primer plano, configuran una auténtica exhibición de poder.

Carlos V aparece representado en el centro de la imagen, en un segundo plano, montado sobre un caballo alazán con su correspondiente gualdrapa. Se cubre con gorra y visera, y lleva un bastón de mando y el collar del Toisón de oro. La imagen coincide bastante con la ofrecida por Santa Cruz, quien afirma que Carlos $\mathrm{V}$ «salió muy gentilhombre cabalgando en un caballo turco con una maza de armas en la mano». Frente al césar desfila un imponente cuerpo de caballería pesada, revestida con brillantes armaduras y lujosas bardas. Probablemente se corresponda con el momento, descrito por Santa Cruz, en que «hecho un escuadrón de 700 de caballo hizo que diesen vuelta por el campo y después entrasen de tres en tres por la ciudad hasta palacio; túvose por cierto que entraron en la ciudad este día 1400 de a caballo». En la crónica se describe con gran atención la apariencia de los principales señores, con sus

a Barcelona: donde reconosciendo los aparejos que ally hauia mandado prouuer: hace muestra o alarde de los / grandes caualleros de su casa y corte acabadas de Juntar las armadas que ally hauian de venir. Postero dya de Mayo se hizo a la uela: lleuando ensu compañia al Infante / don Luys su cuñado que con muchos caualleros portugueses uenya a hallarse en la Jornada. toca en mallorca y menorca y con tiempo algo rezyo pasa por el golfo de leon a cerdeña donde halla el armada que el marques del gasto traya de Italia como se representa en la primera pieça que es la carta de marear y assy de muchas hecha una: de mas de 300 uelas prosigue el emperador su viaje en Africa». En W. Seipel y G. Kugler, Der Kriegszug. 
símbolos heráldicos, armas, número de tropas, etc. Por lo que respecta a las identificaciones, la propuesta más defendida en la actualidad es que se trataría, en el caso de las dos figuras sobre caballos blancos, con lujosas armaduras y tocados con gorras, del duque de Alba y el marqués de Mondéjar. ${ }^{20}$ También la figura central, el joven con brioso corcel y armas lujosas, ha sido identificada en ocasiones con don Luis de Portugal. La edad del cuñado del emperador era bastante superior en el momento de la campaña, por lo que difícilmente sea él. Ciertamente, estas identificaciones son complejas, y la imagen no se corresponde con la descripción de Santa Cruz, tan coincidente en general. Así, el duque de Alba «salió vestido de brocado pelo y las cubiertas del caballo de lo mismo, y 20 caballeros armados y un paje y ocho lacayos con sus arcabuces»; por su parte, don Luis de Portugal «salió de tela de plata frisada con bordaduras coloradas, y cuatro hombres de armas y un paje vestidos de terciopelo pardo».

\section{El desembarco en La Goleta}

En el tercer tapiz se narra la llegada y desembarco de la flota imperial en las costas africanas, así como las primeras escaramuzas con las tropas de Barbarroja [Fig. 3]. El viaje de la fuerza naval es descrito gráficamente en el primer paño de la serie, y también se hace referencia en la cartela del segundo. La complejidad de la operación anfibia de desembarco se muestra en el tapiz, cuya cartela principal ${ }^{21}$ es prácticamente una transcripción literal de la crónica de Santa Cruz: «Entró con las galeras en Puerto Farina, donde estaba la ciudad que antiguamente llamaban Utica, y cuatro horas después llegaron las naves, que por no serles el tiempo favorable habían ido muy bajas, y pasó de allí costeando la armada en buen orden». ${ }^{22}$ También en gran coincidencia con la cartela, Santa Cruz explica como Carlos V se acercó a la Goleta «la cual pasó el Emperador a reconocer con algunas galeras después de surta la armada, donde comenzaron á jugar de una parte á la otra con muchos tiros gruesos de artillería». ${ }^{23}$ Tras desembarcar, las tropas imperiales rápidamente tomaron

20. ChecA, Tesoros.

21. «Entra el Emperador con las galeras en puerto farina que es dela ciudad que antiguamente llamauan utica y quatro oras después llegan las naues: que por ser viento escasso y van mas baxas. passa de aqui costeando la armada en la buena orden que la puso / el principe doria el qual despuees del emperador lleua el principal cargo della. Y llega hasta ponerse en el puerto de la famosa Cartago. Donde surta casi toda ella passa el emperador con algunas galeras a resconocer la goleta. Tirantes duna parte y de otra algunos golpes / de artillería. Otro dia de mañana a XVI de Junio se comienza a desembarcar la infanteria de manera que de un golpe decienden en tierra doze mil infantes de todas tres naciones y juntamente el emperador con los grandes y cavalleros de su casa y corte. Toma tres lugares: / questan en el cabo de cartago de los quales el uno aun retiene el nombre de aquella grand ciudad. El mesmo dia desde las galeras el artillería combate las dos torres del agua y de la sal questan en la ribera. Y los enemigos las des mamparas. Hazense algunas escaramuzas / donde el marques del gasto que después del emperador lleua el principal cargo del exercito por tierra con algunos arcabuzeros españoles: da sobre los enemigos: los quales aqui pierden alguna gente y cauallos». En W. Seipel y G. Kugler, Der Kriegszug.

22. Santa Cruz, Crónica, p. 263.

23. Ibid., p. 263. 


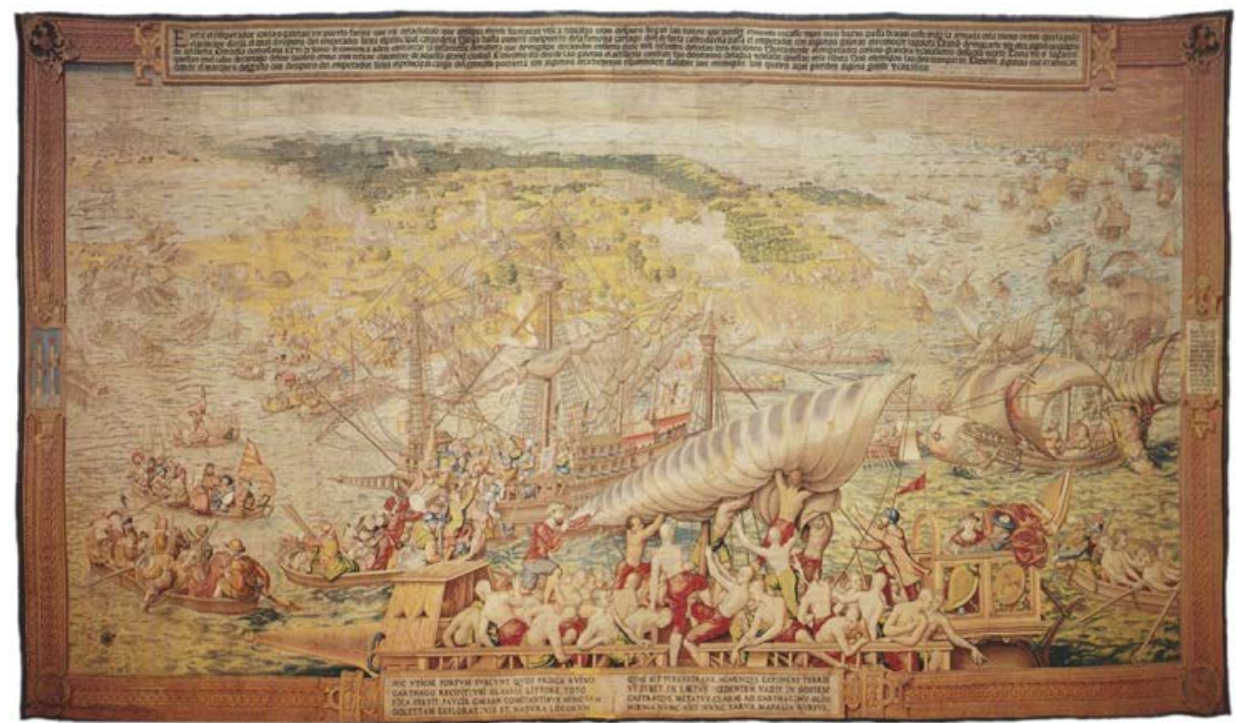

Fig. 3. Jan Cornelisz Vermeyen (diseño) y Willem de Pannemaker (realización), El desembarco en La Goleta, Bruselas, 1548-1554, $529 \times 946 \mathrm{~cm}$. Madrid, Patrimonio Nacional. PN Inv.-Nr. A225-10762, S.13/3 (original)

tres enclaves defensivos, las Torres de la Sal y el Agua, así como la fortificación que había junto a los restos de Cartago, como describen la imagen, la cartela del tapiz y las crónicas, encontrándose con una resistencia inicial repelida por el marqués del Vasto. ${ }^{24}$

La complejidad de la acción militar y su duración durante varios días se unifica en el tapiz en una única vista general donde se recoge la llegada de la flota, el desembarco y las primeras escaramuzas en la costa. Este interés geográfico es compartido por la crónica de Santa Cruz, cartógrafo de profesión, quien le da al espacio tanta importancia como en los tapices, ya que realiza una atenta descripción de la ciudad, el Estaño, la Goleta y las ruinas del antiguo acueducto. ${ }^{25}$

\section{Escaramuzas en torno a La Goleta}

La acción bélica que determinó la victoria de Carlos V en la «Jornada» de Túnez fue la conquista de la fortificación conocida como La Goleta, ocupando

24. «Su Majestad mandó al Marqués del Vasto que saliese algunos arcabuceros y fuesen adonde los moros estaban para reconocer cuanto sfuesen, é ido trabó con ellos cierta escaramuza, y les hizo retirar con su artillería una gran pieza de allí». SAnTa Cruz, Crónica, p. 266.

25. Túnez «que está de la vieja Cartago a 15 millas, y tiene de circuito cinco; tiene un buen alcázar, no tan fuerte cuanto vicioso por las pocas guerras que los moros habían tenido muchos años había»; por su parte, el Estaño es «un gran baño de agua de largura de 12 millas y de ancho de cinco que está entre él y la mar», y se refiere al acueducto ecribiendo que «es un antiguo edificio de un puente sobre unos grandes y fuertes arcos por donde venía antiguamente el agua a Cartago». SANTA Cruz, Crónica, pp. 265-266. 


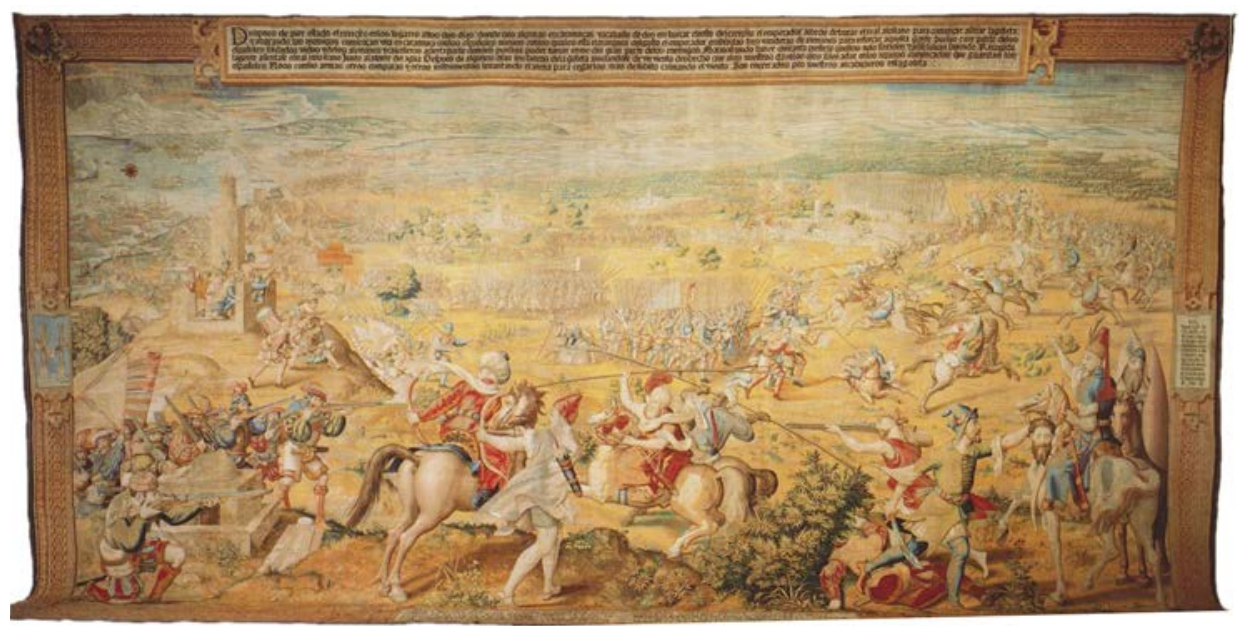

Fig. 4. Jan Cornelisz Vermeyen (diseño) y Willem de Pannemaker (realización), Escaramuzas en torno a La Goleta, Bruselas, 1548-1554, $525 \times 925 \mathrm{~cm}$. Madrid, Patrimonio Nacional. PN Inv.-Nr. A229-6245, S.13/4 (original)

cuatro paños de la serie [Fig. 4]. Era la pieza clave en el sistema defensivo de la ciudad, al bloquear el estrecho canal que conducía al gran puerto natural del Estaño. Las cartelas ${ }^{26}$ del tapiz refieren al alzado del campo imperial, así como a los primeros choques en las inmediaciones de La Goleta. La imagen representa, concretamente, la escaramuza en la que se vieron implicados el marqués del Vasto y el mismo Carlos $\mathrm{V}$, al aprovechar los turcos el momento en que el ejército imperial se desplazaba desde los primeros enclaves tomados a la ubicación de su definitivo campamento. ${ }^{27}$ En el tapiz se aprecia a las tropas

26. «Despues de auer estado el exerçito en los lugares altos dos días: donde ouo algunas escaramuças. y acabado de desembarcar el resto del exerçito: el emperador acordó debaxar el real atollano para començar asitiar la goleta. / y abaxando: los enemigos comiençan vna escaramuça con los españoles nueuos con los quales esta el marques del gasto. El emperador enbiadas tres vanderas de alemanes parea reforcar aquella gente: buelue con parte de los espannoles soldados viejos y de los alemanes y caualleros a cierta parte: donde se pensaua. Poder tomar en medio gran parte de los enemigos. Mas no se pudo hazer con tanta presteza quellos no lo sintiesen: y asi se saluan huiendo. Recogida / la gente asiéntase el real en lo llano junto a la torre del aqua. Despues de algunos dias los turcos de la goleta aiudandose de vn viento deshecho que a los nuestros da en los ojos: salen a dar en los reparos començados que guardan los / espannoles. Unos con sus armas: otros con palas y otros con jnstrumentos leuantando el arena para cegarlos: / mas de subito calmando el viento. Son ençerrados por nuestros arcabuzeros en la goleta». En W. SeIPEl y G. Kugler, Der Kriegszug.

27. «Y comenzando caminar, como los moros que venían en su retaguardia fuesen muchos, se metieron entre los dos lugares que guardaban los italianos y españoles nuevos, y viendo esto el Marqués del Vasto que iba en la retaguardia... fue con toda la arcabucería a dar socorro a los cristianos que andaban muy trabados con los moros en Dahamun y Chubel, y así se trabó en estos lugares muy gran escaramuza que andaba en la retaguardia; por la mucha morisma que había venido mandó a los Capitanes volver los escuadrones la vuelta de los moros, y Su Majestad con su caballería se fue delante de ellos hasta llegar donde primero estaban los cuarteles, y mando allí quedar á los españoles viejos, y á los italianos y á los alemanes que fuesen en socorro de los españoles y del Marqués, y los moros... no osaron esperar; dejando muchos moros muertos y heridos». Santa Cruz, Crónica, pp. 267-268. 
españoles que, dirigidas por el emperador, y gracias al fuego de su arcabucería, repelen los ataques de los jinetes musulmanes, al tiempo que empiezan a recibir refuerzos.

El texto de la cartela se cierra con la referencia a otro de estos ataques enemigos, una salida hecha por los turcos de La Goleta aprovechando una tormenta de arena. En cambio, en las crónicas solo hacen referencia Cereceda ${ }^{28}$ y Santa Cruz. ${ }^{29}$

\section{El sitio de La Goleta}

El quinto tapiz muestra un momento de las acciones bélicas prácticamente sincrónico al anterior, pero desde un punto de vista distinto, e incluye otros hechos de armas un poco posteriores: aparece una panorámica tomada desde el mar, contemplando el cabo de Cartago, con la fortaleza de La Goleta a la izquierda, protegiendo el acceso al Estaño y Túnez [Fig. 5]. ${ }^{30}$ Así, se representa en el paño el complejo proceso de desembarco y organización del campamento. La cartela ${ }^{31}$ no se corresponde con la imagen principal, pues dicho desembarco ya había sido explicado anteriormente. Para evitar la redundancia se narran algunos de los enfrentamientos posteriores, que vemos reflejados en pequeño formato en el tapiz: concretamente, las inscripciones explican el combate en el que murió el conde de Sarno y otras salidas protagonizadas por los defensores de La Goleta, descritos también en el relato de Santa Cruz. ${ }^{32}$ Igualmente se

28. Cereceda, Tratado, p. 37.

29. «Salieron los turcos y moros de La Goleta... por ser el tiempo de recio viento que daba a los cristianos en la cara, que con gran trabajo podían tener los ojos abiertos por la mucha arena que el viento traía, la cual ellos traían aventando con palas, y como vieron gran defensa en los cristianos porque iban cuatro banderas en su socorro, se volvieron». SANTA CRuz, Crónica, p. 271.

30. ChecA, Tesoros.

31. «Salen demañana los turcos dela goleta y combaten un bastion que con gente italiana guarda el conde de sarno. Y matan al conde y algunos soldados suios: y toman les una bandera. Son socorridos de los soldados viejos españoles que a la parte de la mar / guardan otro bastion: que ellos hazen. Otro dia antes que amanezca tornan a salir y dan sobre los mesmos españoles. Y retiran los del bastion matando algunos y entre ellos un alferez a quien toman la bandera: mas luego en continente los / españoles rebuelven y los hechan del reparo. y matando algunos los meten en la goleta. matan estos dias enuna escaramuça almarques del ginal coronel de italianos. Viene mulei hazan Rei detunez: con quatrocientos decaballo nobien aderezados. Losquales / por mandado del emperador luego se buelven salvo veinte que le sirvan. Travase una reziaescaramuça: con los que del olivar tiran con unos sac / res. Hieren en la primera arremetida de una gran lançada al marques de mondejar. y despues de aver hecho otras dos / los ginetes. buelven sobre ellos los moros que son muchos mas. Socorre el emperador: huyen los enemigos: y pierden parte de su artilleria y de los suyos. prosiguense los bastiones y trinchera. Traen las galeras rama para las obras». En W. Seipel y G. Kugler, Der Kriegszug.

32. «Á los 23 de Julio, vigilia de San Juan Bautista, por la manyana salieron de la Goleta hasta 2.000 turcos de pié y de á caballo, y fueron la vuelta de un bastión que el Conde de Sarno, italiano, guardaba... salieron cierta parte de italianos á escaramuzar con ellos, y como eran pocos se comenzaron a retirar al bastión con mala orden, y así entraron en él juntos los turcos con los italianos y los ganaron y mataron al Conde de Sarno y le cortaron la cabeza, y asi mismo mataron otras cuatropersonas principales y otra gente, que fueron hasta 60 personas por todas, sin muchos otros heridos, y después que los turcos hubieron hecho este asalto, se comenzaron á retirar llevándose la bandera del Capitán Otaviano, corso». SANTA CRUZ, Crónica, pp. 268-269. 


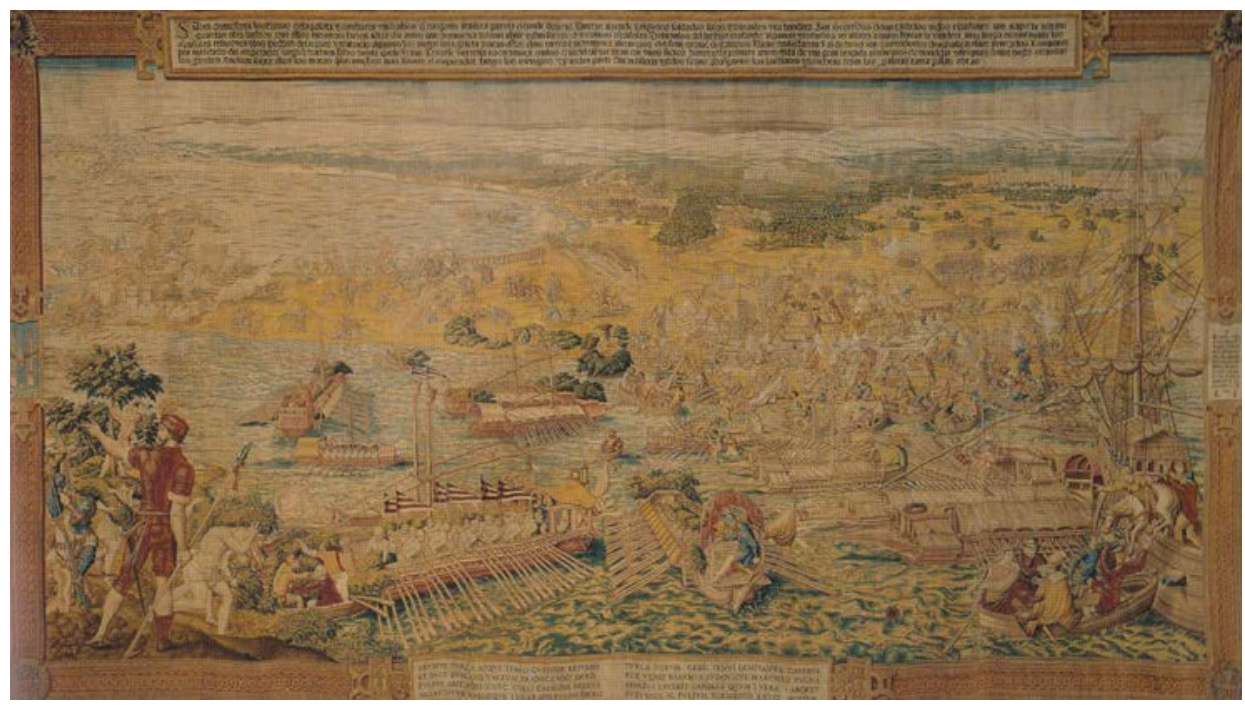

Fig. 5. Jan Cornelisz Vermeyen (diseño) y Willem de Pannemaker (realización), El sitio de La Goleta, Bruselas, 1548-1554, $530 \times 957 \mathrm{~cm}$. Madrid, Patrimonio Nacional. PN Inv.-Nr. A229-6243, S.13/5 (original)

describe como, tras esta salida, los turcos realizaron un nuevo ataque, esta vez contra las posiciones españolas. ${ }^{33}$ Probablemente estas escaramuzas son las que se representan en segundo plano en el tapiz, donde junto a La Goleta podemos ver enfrentamientos en las trincheras, movimiento de banderas (quizá referencia a las robadas), etc. En la imagen no podemos ver, no obstante, otro de los choques armados descrito en la cartela, y que permitió de nuevo al emperador entrar en combate para rescatar al marqués de Mondéjar. ${ }^{34}$

En el tapiz y su cartela también se hace referencia a un hecho diplomático de gran importancia: la llegada del depuesto rey de Túnez, Mulay Hassan, al campamento imperial, que podemos ver en segundo plano, donde es recibido con sus tropas por un grupo de caballeros, dirigidos según las crónicas por el duque de Alba y el marqués de Alarcón. La cartela del tapiz expone que

33. «Á 25 de Junio, una hora antes que amaneciese, salieron muchos turcos y moros de La Goleta y vinieron á un bastión que habían hecho los 4.000 soldados viejos españoles y acometieron á dar batalla por todas partes del bastión, y entraron por encima de él y por la mar que estaba á la orilla del bastión, el cual era bajo, y mataron al Alférez D. Álvaro de Grado y algunos de sus soldados; también mataron al Capitán Luis Méndez de Sotomayor, e hirieron a otro Alférez y mataron é hirieron otros muchos y buenos soldados». SANTA CRuz, Crónica, p. 269.

34. «Y a los 26 de Junio, un sábado mañana, vinieron a los olivares y comenzaron á tirar con tres piezas de artillería á los pabellones,... yendo el Marqués de Mondéjar con los jinetes en la avanguardia; y como la morisma fuese tanta de á caballo y de pie, cargaron muchos sobre el Marqués de Mondéjar... le dieron una lanzada en las espaldas, y como el Emperador, que venía tras el Marqués, le viese á él y sugente en tan grande aprieto, se fue con su lanza en la mano contra los moros, diciendo ¡Santiago, Santiago!, con tan determinado ánimo que no paró hasta donde tenían las tres piezas de artillería, y alanceando los artilleros que allí estaban ganó la una pieza de ellas, que era un grueso pasavolante». SANTA CRUz, Crónica, p. 270. 
llegó con una tropa reducida, rechazada por el emperador. En cambio, Santa Cruz describe como Carlos V «lo recibió muy alegremente echándole los brazos encima de sus hombros, saludándole con amorosas palabras, y lo hizo aposentar muy bien». ${ }^{35}$

Otra cuestión interesante del tapiz es la aparición en su parte derecha de un grupo de esclavos cargando suministros en las galeras. Esta cuestión es especialmente importante, pues la intendencia fue una de las principales dificultades de la campaña. Entre los cronistas solo hace referencia Santa Cruz, explicando como Carlos V mandó «á las galeras que trajesen rama para las obras y los forzados que sirviesen de gastadores». ${ }^{36}$

\section{Búsqueda de alimento para los animales}

El sexto paño de la serie presenta una nueva imagen de los combates previos al asalto definitivo sobre la fortaleza de La Goleta [Fig. 6]. Las cartelas ${ }^{37}$ se refieren a las salidas constantes desde el bastión, aprovechando momentos en que los soldados de Carlos V buscan vituallas en territorio hostil. Al igual que la imagen del tapiz, son indicadoras bastante claras de la posible vinculación de los paños con Santa Cruz, ya que el texto tejido sigue de forma muy similar el escrito en su crónica, especialmente en la primera parte, centrada en los problemas del marqués de Alarcón para conseguir forrajes. ${ }^{38} \mathrm{Al}$ igual que en el relato escrito, en la escena vemos como la caballería de Barbarroja, escondida entre olivos, intenta sorprender a las tropas imperiales del marqués de Alarcón, siendo socorridas por Carlos V al frente de su caballería. Posteriormente fue el duque de Alba quien, con mayor número de tropas, consiguió las tan necesarias provisiones.

Como podemos ver comparando este texto con el de la cartela, ambos coinciden en gran medida. Cabe destacar el contraste entre la importancia que se ofrece a estas escaramuzas en la serie de paños, destinando este sexto tapiz entero a recogerlos, y su escasa presencia en el resto de crónicas: junto a Santa Cruz solo Sepúlveda hace referencia, pero presentando una versión ligeramente distinta de los hechos. Las restantes crónicas sí recogen, en

35. Santa Cruz, Crónica, p. 271.

36. Id.

37. «Despues que aviendo necesidad de vitualla para los cauallos: el marques alarcon fue por ella: y cargaron tantos moros sobrel. que fue necesario ser / socorrido y le socorrio el emperador con alguna gente de a cavallo y de pie. Otro dia va el duque dalua con mayor numero de gente. y trae prouision / abundante. Al tiempo que buelve salen los turcos de la goleta a medio dia contra los espannoles y otros soldados que guardan los reparos. trauase vna / gran escaramuça. son los turcos ençerrados con alguna perdida de los suios en la goleta. llegan nuestros soldados a subir peleando sobre los reparos / della. donde al retirar por ser el trecho largo y el descubierto reciben mucho danno de los arcabuzeros y artilleria de los enemigos». En W. Seipel y G. Kugler, Der Kriegszug.

38. «Por causa de la mucha necesidad que los caballos tenían de vituallas, hubo de ir el Marqués de Alarcón por ellas, y cargaron tantos moros sobre él que fue necesario ser socorrido, y así fue el Duque de Alba con mayor número de gente y trajo abundante provisión». SANTA CRUz, Crónica, p. 272. 


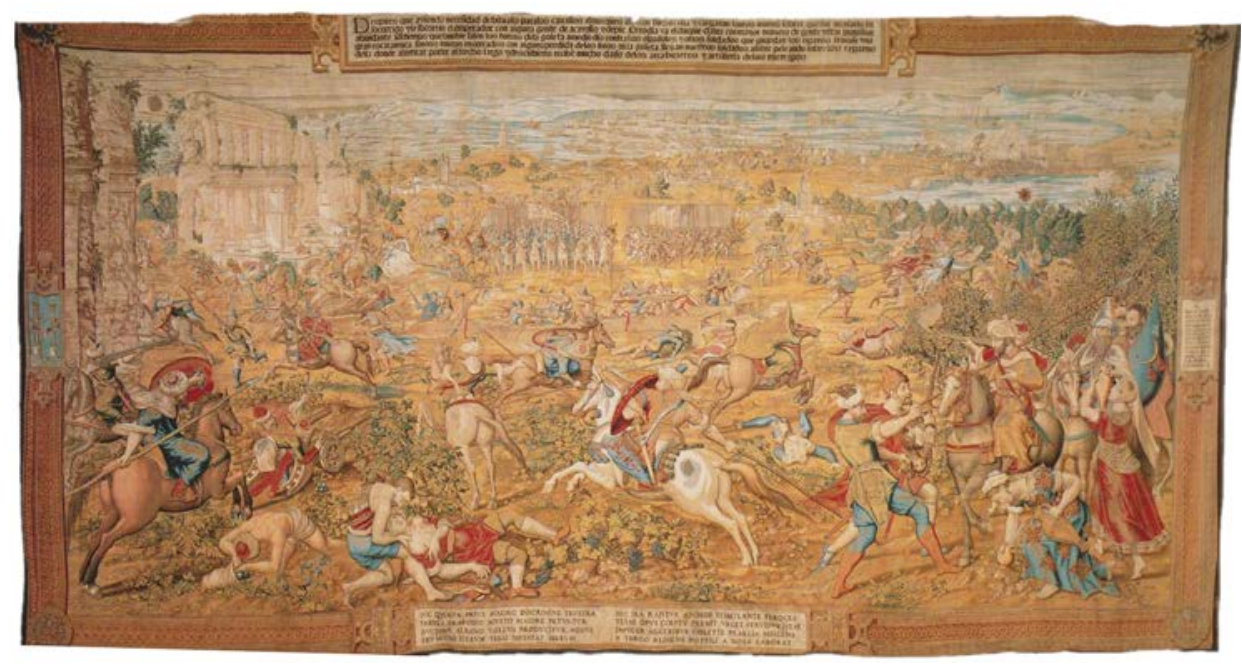

Fig. 6. Jan Cornelisz Vermeyen (diseño) y Willem de Pannemaker (realización), Búsqueda de alimento para los animales, Bruselas, 1548-1554, $524 \times 937 \mathrm{~cm}$. Madrid, Patrimonio Nacional. PN Inv.-Nr. A257-7448, S.13/6 (original)

cambio, el otro choque armado al que hace referencia la cartela principal del tapiz, en el que Cachidiablo y sus turcos realizan una salida por sorpresa desde La Goleta, siendo rechazados por los españoles. ${ }^{39}$

\section{La toma de La Goleta}

En este séptimo paño se representa el asalto definitivo a la fortaleza corsaria [Fig. 7]. Tras un mes de preparativos, el 14 de julio se lanzó el ataque bajo las órdenes del césar. ${ }^{40}$ Previamente a este ataque masivo, como narra la cartela del tapiz ${ }^{41}$ los turcos realizaron un último ataque desesperado para evitarlo,

39. «Salieron de La Goleta más de 500 turcos y genízaros con una bandera, y vinieron a los bastiones que guardaban los soldados viejos, y con muy determinado animo entraron por encima del bastión y por orillas de la mar y hicieron retirar la poca guardia que había y ganaron cerca de 500 pasos del bastión; y como estoviesen los soldados viejos,..., arremetieron contra los turcos y los hicieron salir del bastión y los fueron siguiendo hasta hacerlos encerrar en La Goleta, de la cual tiraron á los españoles con la artillería y escopetería». SANTA Cruz, Crónica, p. 272.

40. «Todos los demás del ejército mandó meter dentro de una trinchera ó bastión, y hechoe sto se plantaron los cestones y se puso la artillería para dar batería á La Goleta». SANTA Cruz, Crónica, p. 273.

41. «Recogese el exercito mas y las trincheras y rreparos se acercan a la goleta para asentar la artilleria. En estos dias combaten hasta veinte mil ombres de los enemigos a la torre o atalaia que en el cabo de cartago guardan XVI soldados españoles. Los quales siendo / apretados con fuego: yescopeteria y puestos en gran necesidad, son socorridos del emperador con parte de los alemanes y gente nueva española: batese la goleta por tierra con XL pieças de artilleria: y por mar con LX galeras ordenadas por el principe doria / al qual traia el emperador consigo para proveer en las otras cosas con su consejo. Tambien el galeon y carauelas portiguesas. Y el del principe y la carraca de la religion. Combaten reziamente y con nuestras galeras dos carabelas portuguesas llegan a batir con grande animo. Defienden a la goleta con mas de quatroçientas 


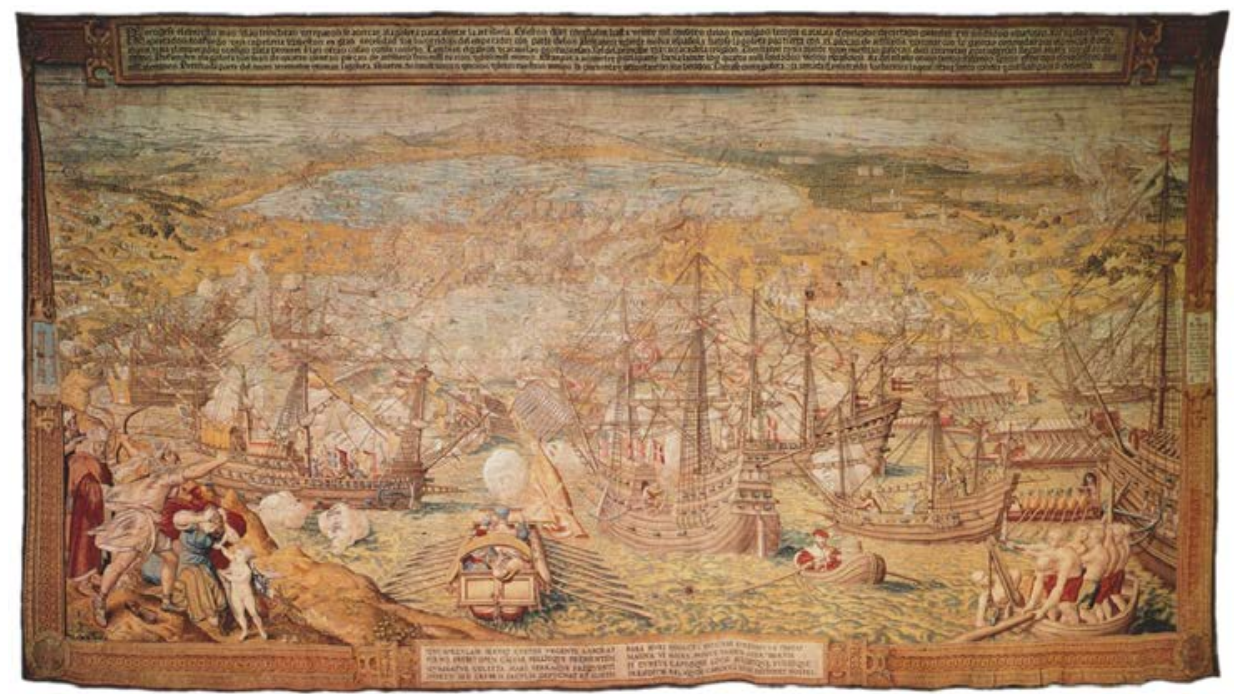

Fig. 7. Jan Cornelisz Vermeyen (diseño) y Willem de Pannemaker (realización), La toma de La Goleta, Bruselas, 1548-1554, $512 \times 992 \mathrm{~cm}$. Madrid, Patrimonio Nacional. PN Inv.-Nr. A227-6203, S.13/7 (original)

concretamente contra la torre de Chubel. En el paño se representa en segundo plano a la derecha, con su correspondiente correlato escrito por Santa Cruz. ${ }^{42}$

Frustrados estos intentos por frenar la ofensiva imperial, tal y como vemos en la monumental vista del tapiz, el ataque se organizó como una compleja acción combinada entre las tropas de tierra y la flota. Las distintas crónicas, como la de Santa Cruz, narran de forma muy nítida la complejidad y potencia del operativo bélico. ${ }^{43} \mathrm{Al}$ fondo de la escena se vislumbra el ataque terrestre.

pieças de artilleria seis mill turcos: y dos mil moros. Estan para acometer por la parte hazia la mar los quatro mill soldados viejos españoles. ala del estaño otros tantos italianos. Y entre estos dos escuadrones dos / mill alemanes: Derribad parte del muro arremeten ytoman la goleta. Mueren dos mill turcos y moros y de los nuestros menos de çincuenta y otros tantos son heridos. Tomase con la goleta la armada que avia traido barbarroxa la qual estava junto con ella y con su amparo se defendia». En W. SeIPEL y G. Kugler, Der Kriegszug.

42. «Este día vinieron muchos moros sobre los doce soldados que habían quedado en Chubel, y ellos se procuraron defender con los arcabuces y mosquetes que tenían, é hicieron ahumadas pidiendo socorro viendo la mucha morisma que sobre ellos había, y el Emperador visto el aprieto en que estaban mandó á la caballería y parte de la infantería española que lo siguiesen, y con su lanza en cuja se fue la vuelta de la torre á socorrerlos, y así se metió entre los moros y se trabaron los unos con los otros, de manera que los moros con mucho daño suyo dejaron la montaña y torre y se volvieron». SANTA Cruz, Crónica, p. 273-4.

43. «Miércoles, muy de mañana, se comenzaron á tocar las trompetas y tras esta música se comenzó la de la artillería, la cual batía de tres partes: la una estab avecina á la marina, donde estaban 21 piezas de artillería, y con ésta estaba el Emperador; otra estaba junto á la albuhera, donde estaban 15 piezas gruesas de artillería, y en medio de estas dos había otra batería con sus cañones gruesos, todas apartadas de La Goleta 400 pasos, y por la mar se llegaron la carraca de Rodas y el galeón de Portugal, y el del príncipe Andrea Doria y las carabelas, y comenzaron á tirar á La Goleta con su artillería,... y las galeras salían de ocho en ocho á tirar y se retiraban después de haber tirado, y luego venían otras tantas, y de esta manera jamás dejaron de batir por mar y por tierra, por manera que se acortaron mucha parte de los bastiones y murallas del castillo y revellín que delante tenían». SANTA Cruz, Crónica, p. 274. 
Protegidas por las trincheras y el fuego artillero, las tropas de Carlos V se acercan paulatinamente al fuerte turco, dispuestas a lanzar el ataque definitivo una vez castigados de manera extrema los muros del enclave. ${ }^{44}$ Como veremos, la victoria iba a abrir de par en par las puertas al triunfo de Carlos V.

\section{La batalla de los Pozos}

En el octavo tapiz de la serie se representa y narra ${ }^{45}$ la denominada «batalla de los Pozos», último intento por parte de Barbarroja de detener el avance de Carlos V hacia Túnez. Tomada La Goleta, el ejército imperial emprendió la marcha bajo el duro sol africano [Fig. 8]. Consciente de dicha situación, Barbarroja preparó la defensa de la ciudad en el oasis de Casebe, el único lugar con pozas de agua en todo el desértico camino.

El tapiz muestra, precisamente, el momento en que los turcos se lanzan por sorpresa sobre el ejército imperial cuando llega a los estanques, situados en un oasis con diferentes árboles, palmeras, etc. En primer plano aparece una gran poza, en la que los lansquenetes han entrado a refrescarse, llenar recipientes o beber. Los soldados musulmanes les atacan, aprovechando la dificultad que encuentran para moverse. Santa Cruz hace una breve referencia a que el ataque solo hizo daño «en algunos tudescos que quedaban algo fuera del escuadrón cuanto una milla». ${ }^{46}$ Tras esta escena se sitúa un amplio paisaje,

44. El relato narra cómo los capitanes «dijeron al Emperador qué les mandaba, y Su Majestad respondió que lo que á ellos pareciese, y dándoles la bendición y encomendándolos á Dios, arremetieron á la batería en sus escalas, y para ponerlas se echaron en el foso y subieron sobre los bastiones y batería, aunque la resistencia de los turcos y genízaros era mucha, porque luego acudieron allí con mucha artillería y escopetería y flechas y botafuegos y cañones con talegones de piedras con que hacían mucho daño; pero todo les aprovechó poco, porque los cristianos con mucha furia les entraron por todas partes sin poderse defender». Santa Cruz, Crónica, pp. 274-275.

45. «Pospuestas las dificultades que muchos contra la yda de tunez proponian, dexando al principe doria con el armada y para proueer todas las cosas necesarias asi en mar como en tierra, y guarda de la goleta parte el emperador con el exercito en esta orden: la auangardia lleva el marques del gasto con los soldados viejos espannoles a las oliuas y con los jtalianos, cuyo coronel / es el principe de salerno: a la del estanno / y en ella va el marques de mondejar con los ginetes y el marques alarcon con algunos albaneses: la batalla trae el emperador, en la qual van los grandes y parte de los caualleros de su casa y corte, siguiendo el estandarte que lleva su cauallerizo mayor, el Sennor de bosu: aqui van los alemanes y la artilleria que llevan los esclauos con las galeras. En la reta aguarda / viene el duque de alua con la otra parte de caualleros de la casa y corte del emperador y los archeros de la guarda con su guion y dos esquadrones de la jnfanteria nueua española. El carruage entrella y la batalla a la parte del estanio. Auiendo caminado en esta orden dos leguas y algo mas, se muestra en el campo barbarroxa, dexados los pozos atras con XII mil de a cauallo y $\mathrm{C}$ mil peones. / El emperador haze abrir los dos esquadrones de la auanguardia y ponese con la batalla y artilleria en medio, porque la frente del auanguardia sea mas fuerte. Recogense los ginetes detras de la arcabuzeria de la aauanguardia. Comiençase la batalla a tirando la artilleria dentrambas partes, y juntamente combatiendo nuestros arcabuzeros por la parte de los oliuares. Pasa adelante el emperador, huien / los enemigos. Resisten IIIIo mill turcos, cabe los pozos. Entrales los espannoles: matando CCCC dellos. Tomanse siete pieças de artilleria. Quedan muertos de los enemigos poco mas de seis çientos. Barbarroxa se rretira a tunez. buelue el emperador y asienta el real. cabe los pozos de que los nuestros traen gran necesidad por sed y calor jncomportable». En W. Seipel y G. Kugler, Der Kriegszug.

46. Santa Cruz, Crónica, p. 277. 


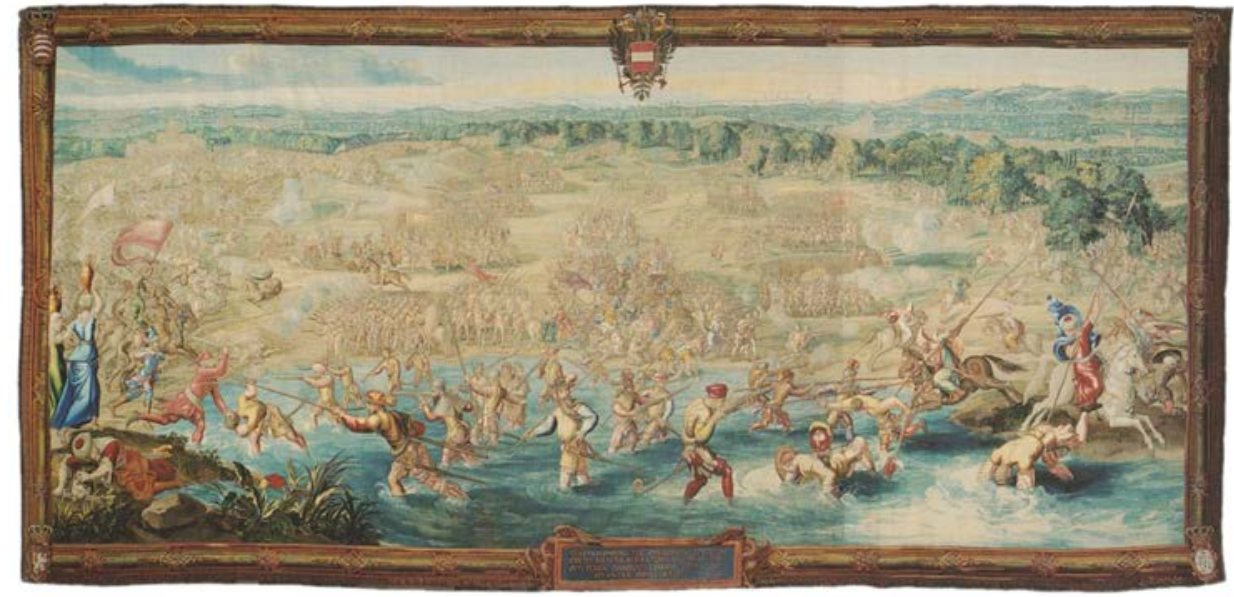

Fig. 8. Jan Cornelisz Vermeyen (diseño) y Willem de Pannemaker (realización), La batalla de los Pozos, Bruselas, 1548-1554, $522 \times 12 \mathrm{~cm}$. Original perdido, copias en Sevilla, Reales Alcázares (Jacobus van der Goten el Joven, 1740, $532 \times 1172 \mathrm{~cm}$ ) y Viena, Tapisseriensammlung, Inv.- Num. T X/4 (J. de Vos, Bruselas, 1712-1721, $531 \times 1138 \mathrm{~cm}$ ).

La imagen corresponde a esta serie

donde podemos ver la caballería y los cañones de Barbarroja atacando desde todos los lados a las tropas imperiales. El ejército de Carlos V, no obstante, no se deja sorprender, barriendo a las filas enemigas. ${ }^{47} \mathrm{Al}$ mismo tiempo que contemplaba cómo sus tropas eran derrotadas, Barbarroja recibió la noticia de la revuelta de los prisioneros cristianos dentro de la misma ciudad de Túnez: la suerte de la campaña estaba echada. ${ }^{48}$

\section{La toma de Túnez}

Los paños noveno y décimo de la serie están realizados para ser vistos de forma conjunta, generando una monumental panorámica de más de 16 metros de largo donde se recoge la ocupación y saqueo de Túnez [Figs. 9 y 10].

47. «... el Emperador llegó con sus escuadrones á tiro de artillería donde estaba Barbarroja, los mandó afirmar, y la morisma comenzó tirar con su artillería junto a los cristianos, y el Emperador mandó a sus artilleros que tirasen á los moros». SANTA CRuz, Crónica, p. 277.

48. Manuel Fernández Álvarez: Carlos V, el César y el Hombre, Espasa, Madrid, 1999. 


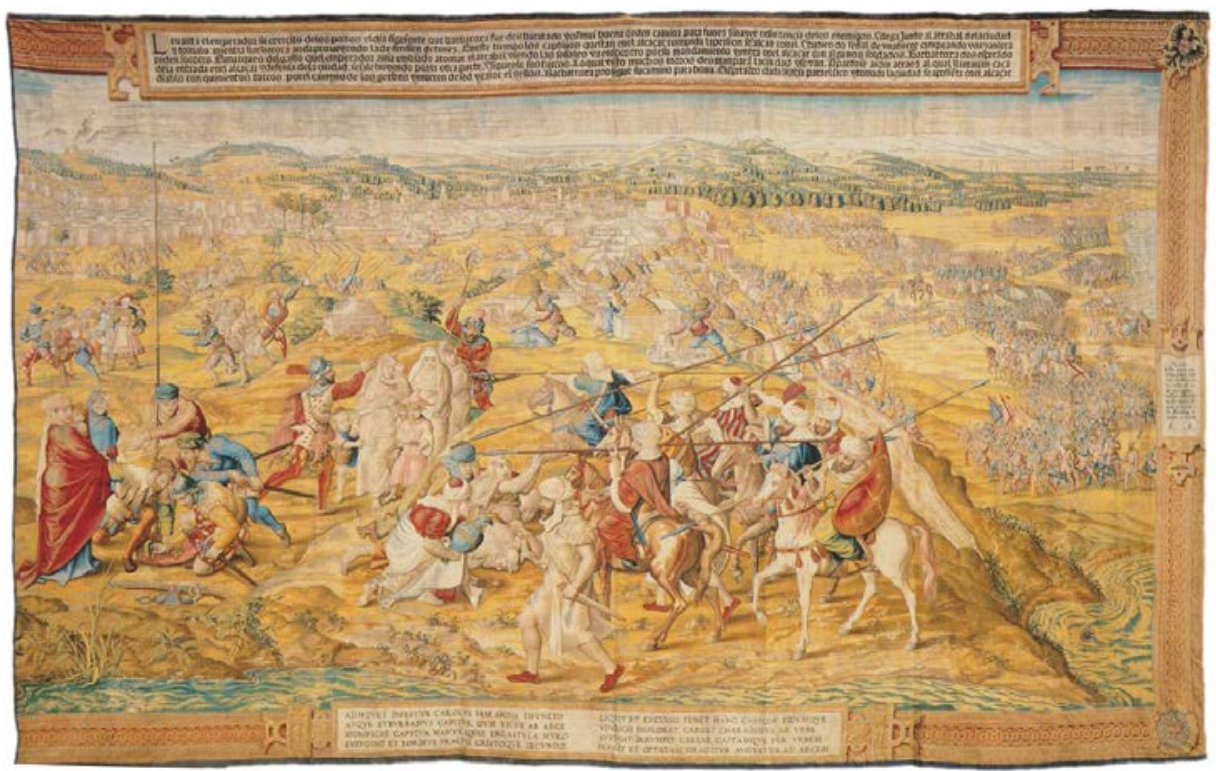

Fig. 9. Jan Cornelisz Vermeyen (diseño) y Willem de Pannemaker (realización), La toma de Túnez, Bruselas, 1548-1554, $527 \times 835 \mathrm{~cm}$. Madrid, Patrimonio Nacional. PN Inv.-Nr. A371-12657, S.13/9 (original)

Siguiendo la narración de la cartela ${ }^{49}$ y la de Santa Cruz, al día siguiente de su victoria en Casebe el emperador levantó el campo para, manteniendo la formación, marchar sobre Túnez: «Aquel día quedó el ejército en los olivares haciéndose muy gran guarda, y otro día la mañana caminaron los escuadrones en la orden que hasta allí habían llevado la vuelta de Túnez, que estaba de allí dos millas». ${ }^{50}$

Anteriormente, la llegada de Carlos V propició que los cerca de 20.000 cautivos que estaban prisioneros en Túnez se alzaran y ocupasen la alcazaba, hechos descritos por Santa Cruz con gran detallismo. ${ }^{51}$ Barbarroja, derrotado

49. «Levanta el emperador su exerçito de los pozos el dia siquiente que barbarroxa fue desbaratado y con mui buena orden camina para tunez sin aver resistençia de los enemigos. Y llega junto al arrabal de la ciudad / y tomalo: mientras barbaroxa anda proueyendo la defension de tunez. En este tiempo los captivos que stan en el alcaçar rompida la prision se alçan con el. Y haciendo sennal de vna torre campeando una bandera / piden socorro. El marques del gasto quel emperador auia embiado a tomar el arrabal viendo las sennales va en socorro por su mandamiento y entra en el alcaçar con algunos soldados. Barbaroxa, desesperando / de la entrada en el alcaçar y defensa de la çiudad: se sale huyendo por la otra parte. Y siguenle sus turcos. Lo qual visto por muchos moros desmanparan la ciudad y se van. Apartose aidin arraez al qual llamavan caça / diablo con quinientos turcos: por el camyno de los gerbes y mueren de sed y calor el y ellos. Barbaroxa prosigue su camino para bona. El emperador dada liçencia para el saco: y tomada la çiudad: se aposienta en el alcaçar». En W. Seipel y G. Kugler, Der Kriegszug.

50. Santa Cruz, Crónica, p. 278.

51. «Fué el caso que Barbarroja al tiempo que salió de Túnez mandó quemar todos los cristianos que tenía cautivos, que pasaban de 20.000 y estaban todos encerrados en unos baños en la alcazaba, y el Judío no consintió que se quemasen, diciendo que si él había la victoria que los había después menester, y si no 
en la batalla de los Pozos y con una rebelión en la ciudad, se vio forzado a huir gracias a unas galeras que tenía a resguardo en el puerto de Bona. La ciudad, sin apenas oposición, se rindió el día 21 de julio, entrando por la mañana los capitanes Jaén y Bocanegra con sus compañías. La inscripción superior del tapiz refiere la rebelión de los esclavos, la llegada del emperador y la huida del comandante otomano; en el paño podemos ver la aproximación de las falanges imperiales a los arrabales de la ciudad de Túnez, condenada al inminente saqueo.

\section{El saqueo de Túnez}

El décimo tapiz, ${ }^{52}$ complementario del anterior, muestra una amplia panorámica del asalto a la ciudad, visto desde el exterior de sus murallas. A pesar de la inicial oposición del emperador, durante tres días las milicias cesáreas infligieron un despiadado castigo sobre Túnez. El nivel de saqueo fue tal que Manuel Fernández Álvarez solo se atreve a compararlo con el «Saco» de Roma de 1527, realizado también por los lansquenetes imperiales. ${ }^{53}$ Las crónicas ofrecen una visión distinta a la que los historiadores tienen en la actualidad, y coinciden en que el expolio no fue especialmente lucrativo, más allá de la gran cantidad de esclavos capturados: Barbarroja había rapiñado previamente las riquezas de los tunecinos. ${ }^{54}$ Así pues, se hicieron más de 18.000 esclavos, saqueándose la riquísima biblioteca real, la colección de perfumes, etc., que pasarían a Europa favoreciendo la implantación de un gusto orientalizante «a la morisca». ${ }^{55}$

Contemplando la dura escena, sobre una loma, aparece Vermeyen. Le acompaña otro personaje, identificado en ocasiones con su ayudante Pieter

que cuando se retirasen en Túnez serían presto quemados, y los cautivos fueron de esto avisados por un renegado su amigo, y determinaron el día mismo que Barbarroja salió de la ciudad romper las paredes y puertas con los hierros que tenían, y salieron de los baños y se fueron á casas donde sabían que tenían armas y se armaron y se volvieron a la alcazaba y se alzaron con ella, matando á los que estaban dentro». SANTA Cruz, Crónica, p. 278.

52. «Despues que la çiudad se començo a saquear y algunos moros que se defendian en sus casas fueron muertos: toman los soldados a prision y por esclauos toda la gente que de los / enemigos se halla dentro. Que es grand numero: y mucha rropa y algun dinero: que por la priesa de huir los moros no auian podido llevar consigo: ni bien esconder. Hallanse en la / çiudad muchos Christianos captiuos: y en el alcaçar muchos mas. Poque alli auia mandado barbarroxa que se pusiesen en prision todos los esclauos que pudiesen tomar armas con los / que el auia puestos traidos de rreino. Passa el numero de XX mill. personas con muchachos y mugeres de todas naçiones. Los quales este dia son puestos en libertad. Da el emperador su / çiudad y mugeres e hijos que stauan en el alcaçar al rrei de tunez el qual queda por tributario del emperador: aceptando de buena las condiçiones que le quiso poner». En W. Seipel y G. Kugler, Der Kriegszug.

53. Fernández, Carlos V.

54. «Y así se ganó Túnez a 21 de Julio y se hizo una gran matanza en los moros y moras que se hallaron dentro, y el saco no fue tal como se pensaba, porque Barbarroja les había tomado lo mejor y otros se habían salido con el temor de la ciudad y llevando lo que tenían. Tomáronse muchos moros y moras cautivas... y muchos moros rescató el Rey de Túnez». SAnTa Cruz, Crónica, p. 279.

55. Deswarte-Rosa, «L'expédition». 


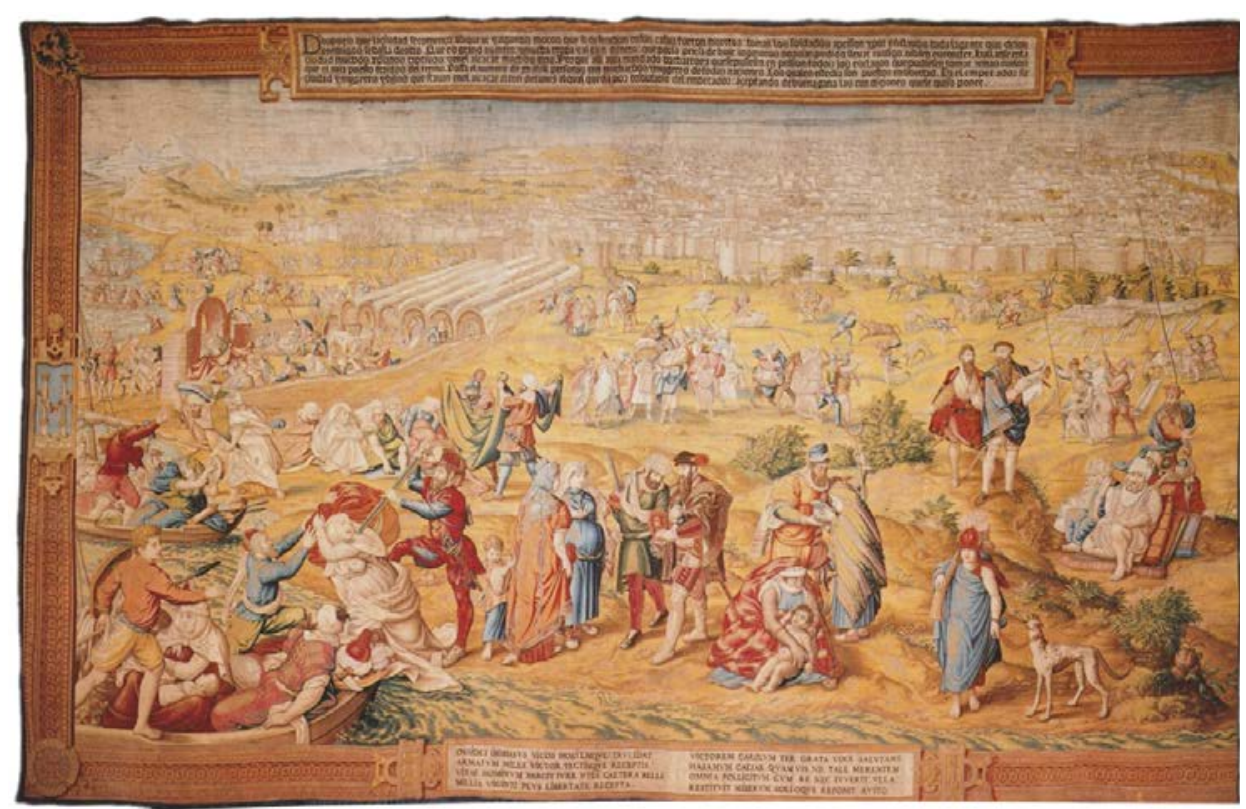

Fig. 10. Jan Cornelisz Vermeyen (diseño) y Willem de Pannemaker (realización), El saqueo de Túnez, Bruselas, 1548-1554, $515 \times 806 \mathrm{~cm}$. Madrid, Patrimonio Nacional. PN Inv.-Nr. A227-6193, S.13/10 (original)

Coecke ${ }^{56}$ o con alguno de los cronistas presentes, quizá Santa Cruz o Felipe de Guevara. ${ }^{57}$ Aparecen tomando notas, como testigos de la acción, cuya aportación, visual y escrita, tendría carácter de verdad oficial, incuestionable.

\section{La salida de Túnez hacia el campamento de Rada}

El paño representa la salida triunfal de Carlos V de Túnez el día 27, marchando con sus legiones hacia Rada, fértil población en el camino hacia La Goleta [Fig. 11]. Desde allí iban a iniciarse los preparativos para el reembarque de las tropas con destino a Europa. Santa Cruz describe en su crónica los últimos acontecimientos de la campaña de manera bastante somera, como es el caso de la marcha del ejército de la capital norteafricana. ${ }^{58}$

56. P. JUnQUera: «Las batallas navales en los tapices», Reales Sitios, 17 (1968), pp. 40-55.

57. CHECA, Tesoros.

58. «Después que la ciudad de Túnez fue ganada y saqueada, se salió Su Majestad de ella con todo el ejército, y se volvió camino de La Goleta y por otro camino que el que había hecho, en el cual estaban dos buenas villas dichas Rabos y Rugo (sic), donde el Emperador se aposentó con su corte y todo su ejército, y estuvo hasta primero día de Agosto en que se fue á La Goleta». Santa Cruz, Crónica, p. 279. 


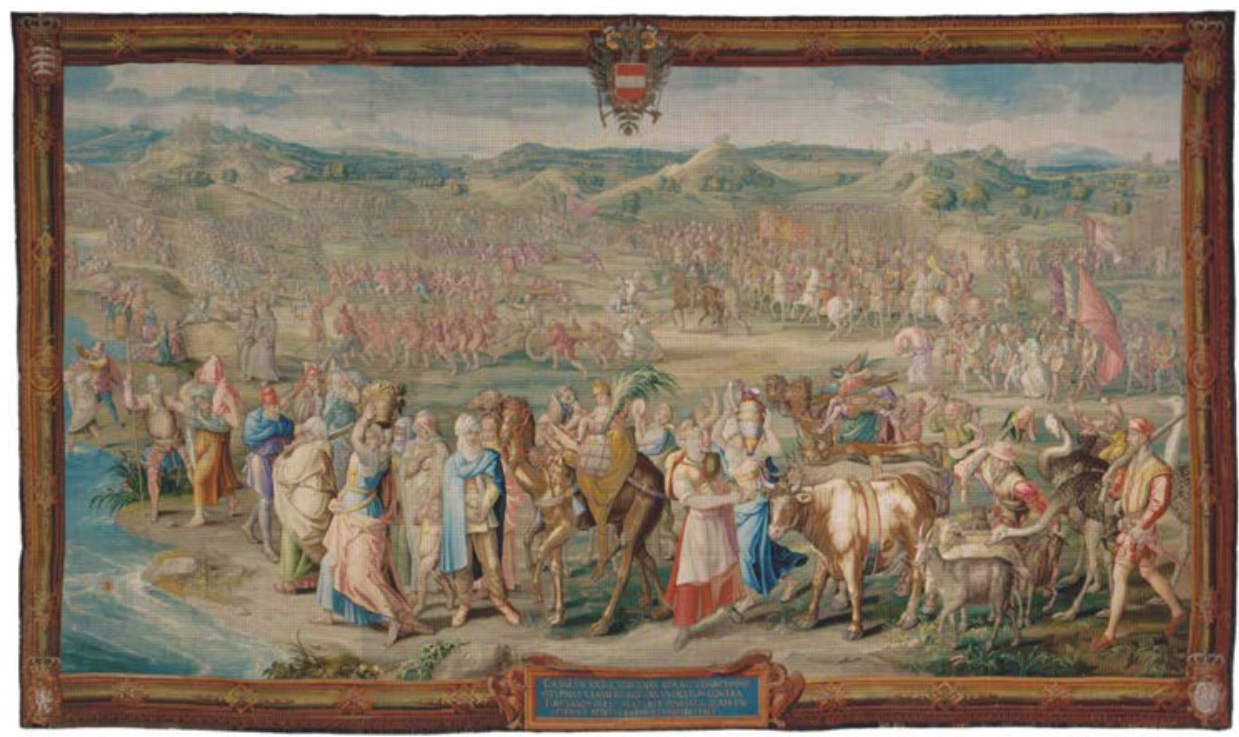

Fig. 11. Jan Cornelisz Vermeyen (diseño) y Willem de Pannemaker (realización),

La salida de Túnez hacia el campamento de Rada, Bruselas, 1548-1554, $522 \times 1.000 \mathrm{~cm}$.

Original perdido, copias en Sevilla, Reales Alcázares (Jacobus van der Goten el Joven, 1740, $554 \times 932 \mathrm{~cm}$ ); Viena, Tapisseriensammlung, Inv.- Num. T X/7 (J. de Vos, Bruselas, 1712-1721, $527 \times 890 \mathrm{~cm})$. La imagen corresponde a esta serie

La imagen recoge el abandono de la ciudad norteafricana, organizándose como un gran cortejo triunfal «a ll'antica». Por su parte, la cartela principal ${ }^{59}$ del tapiz recoge acontecimientos posteriores a la salida imperial. La crónica de Sepúlveda es la única que hace referencia a hechos presentes en el tapiz, como la llegada de población autóctona dispuesta a pagar el rescate de sus familiares, advirtiendo con ramas de olivo de la bondad de sus intenciones: las mismas ramas de olivo que, como hemos visto, le ofrecen en la imagen una serie de personajes al triunfante emperador. También Sepúlveda relata la liberación y ayuda a los cautivos cristianos que habían caído en las garras de Barbarroja. ${ }^{60}$ En claro contraste, el resto de cronistas no hacen prácticamente referencia a estos hechos.

59. «Auiendo estado el emperador ocho dias en tunez hizo salir el exercito y con el se viene a aposentar en Rada, donde / manda que los moros que quisieren venir a rescatar los suyos, lo puedan hazer con seguridad. Vienen muchos a / comprar ropa de los soldados que por el estanno hauian traydo en barcas, otros a rescatar mugeres e hijos y todos / con ramos de oliva en las cabecas, para que se conoçiese de los soldados a lo que venian. Estando alli el emperador / mando dar nauios a los Christianos libertados, cada vno en la nao de su nacion, porque de todos hauia cautiuos y naues». W. Seipel y G. Kugler, Der Kriegszug.

60. Juan Ginés de Sepúlveda: De Bello Africo. Ed. y estudio a cargo de Mercedes Trascasas CASARES, Uned, Madrid, 2005 


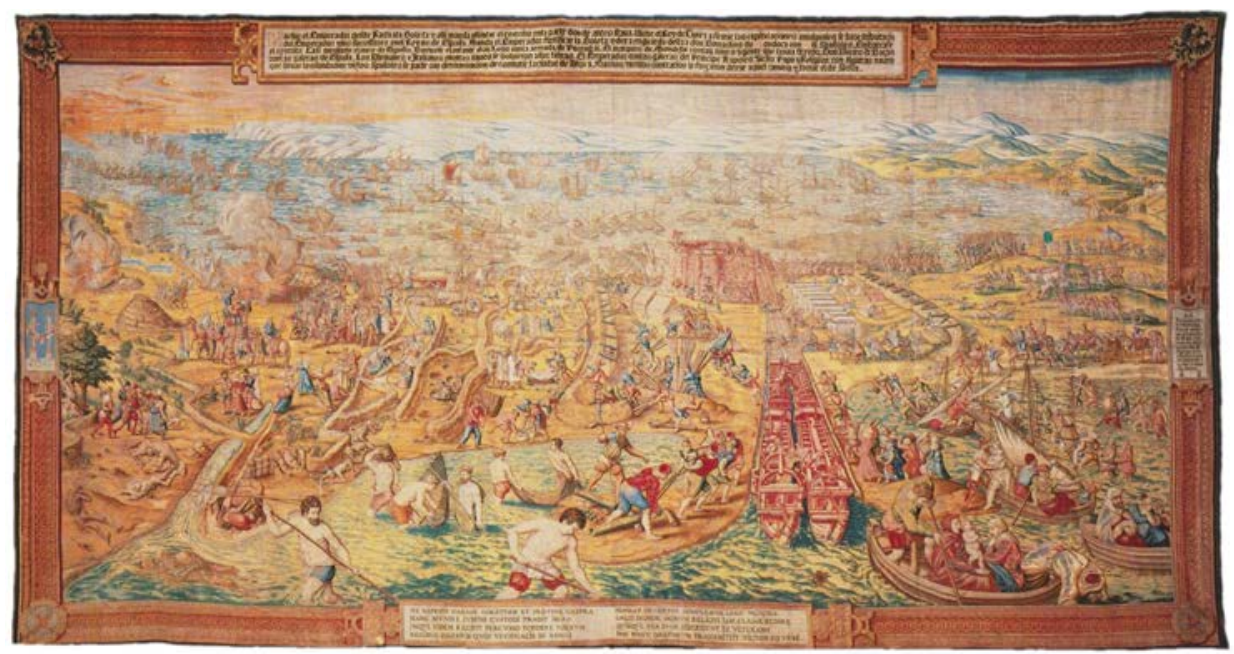

Fig. 12. Jan Cornelisz Vermeyen (diseño) y Willem de Pannemaker (realización), El embarque en La Goleta, Bruselas, 1548-1554, $521 \times 1.002 \mathrm{~cm}$. Madrid, Patrimonio Nacional. PN Inv.-Nr. A371-12658, S.13/12 (original)

\section{El embarque en La Goleta}

La serie de tapices acerca de la «ornada» de Túnez se cierra con esta amplia vista del embarque y salida de la flota imperial del puerto de La Goleta [Fig. 12]. Tras salir de Túnez, Carlos V establece su campamento junto a la «Torre del Agua», última estación antes de retornar a Europa. Todos estos preparativos se muestran y describen en el paño, ${ }^{61}$ y de forma similar en la crónica de Santa Cruz: reforma de La Goleta, establecimiento de guarniciones en distintos puntos fuertes, ${ }^{62}$ destrucción de algunos enclaves que podían ser un peligro para las posiciones españolas... ${ }^{63}$ También el cronista dedica un

61. «Buelue el emperador desde rada a la goleta; y allí manda assentar el exercito en la parte donde antes staua. viene el rey de tunez a firmar las capitulaciones: en las quales se haze tributario / del emperador y sus sucessores en el Reyno de Espanna. Manda el emperador fortificar la goleta: y dexa en guarda della a don Bernaldino de mendoça con mil spannoles. embarcase / el exercito casi mediado el mes de agosto. Bueluese el infante don luys con la armada de Portugal. El marques de mondejar con las naues y la gente que havia traydo. Don aluaro de Baçan / con las galeras de Espanna. Los alemanes e italianos en otras naues se voluieron a sus tierras. El emperador con las galeras del principe: napoles: Sicilia: Papa y religión: con algunas naues / que llevan los soldados viejos Spannoles se parte con determinacion de combatir la ciudad de Africa. Mas los vientos contrarios le forçaron dexar aquel camino y tomar el de Sicilia». En W. SEIPEL y G. Kugler, Der Kriegszug.

62. «Mandó el Emperador que en la Goleta quedasen cuatro Capitanes españoles con sus compañías de los que habían venido de España, [...], y por General mandó quedar a D. Bernardino de Mendoza, hermano del Marqués de Mondéjar, y mandó asimismo quedar en La Goleta a Ferramolín para que la fortificase... y asi mismo mandó Su Majestad que quedasen en Bona otros cuatro Capitanes». SANTA Cruz, Crónica, p. 281.

63. «Mandó que se derribase la Torre del Agua, y micer Benedicto de Ravena, Ingeniero mayor de Su Majestad, la hizo minar y poner ciertos barriles de pólvora debajo, los cuales después que les fue puesto fuego hicieron volar la torre en muchos pedazos». Santa Cruz, Crónica, p. 282. 
capítulo entero al hecho trascendental que ocurre en el grupo de tiendas del centro del tapiz: sentados alrededor de una mesa, Mulay Hassan y Carlos V, acompañados por sus consejeros, están firmando el tratado de paz. Ante ellos, un grupo de mujeres lo celebra bailando. Una vez firmadas las capitulaciones el césar, tal como narra Santa Cruz, dio por culminada de forma exitosa la campaña. ${ }^{64}$

El tercio superior del paño está ocupado por una amplia vista del golfo de Cartago cuyas aguas son surcadas por las galeras imperiales, rumbo a Europa. ${ }^{65}$ El miércoles 18 por la mañana había levado anclas de las playas norteafricanas el cuatrirreme imperial, del cual bajó Carlos V en Trapani, el 22 de agosto de 1535. A partir de este momento el emperador iniciaría un triunfal recorrido por las principales ciudades italianas en las que, en un marco ficticio de retorno a la Antigüedad, fue recibido como un nuevo Escipión, culminado con su nombramiento en Roma, por parte de Pablo III, como «Carolus Africanus». ${ }^{66}$

\section{CONCLUSIÓN}

Siguiendo los planteamientos de F. Checa, la «Jornada de Túnez» y sus consecuencias artísticas actuaron como punto de inflexión en la creación de la imagen madura del emperador. ${ }^{67}$ Multitud de producciones icónicas y textuales, puestas al servicio de Carlos V, confluyeron en la creación de un amplio programa retórico en beneficio de la imagen del césar, descollando especialmente la serie de tapices y las distintas crónicas bélicas. Con nuestro trabajo, por tanto, creemos aportar consistencia al concepto que entiende este conjunto de paños como una especie de «crónica tejida», vinculada fundamentalmente con el relato de Santa Cruz, y no solo como motivo de inspiración temática, sino como parte de un proyecto amplio de construcción de una «verdad» histórica tamizada por los intereses de la corte carolina. La imagen de los tapices y el texto de cartelas y crónica convergen en la articulación de un relato común, estableciendo un «funcionamiento sincrónico» que devino en un entramado icónico-literario puesto al servicio del emperador.

64. «Hecho esto y viendo Su Majestad que no había posibilidad de hacer la empresa de Argel, así por ser tan larga la navegación desde Túnez á ella y siendo ya casi pasado el verano, como por estar la gente cansada y fatigada del trabajo que había pasado, así de calores como de falta de vituallas, por donde la mayor parte de ella había adolecido de calenturas y otras indisposiciones, y así se resolvió Su Majestad de deshacer la dicha armada y ejército, y mandó embarcar a toda la gente». SANTA Cruz, Crónica, pp. 281-282.

65. «A los 13 de Agosto se embarcaron los 4.000 españoles soldados viejos, y á los 17 salieron de La Goleta el galeón y naos y carabelas de Portugal para volverse á su Reino, y otro día siguiente salieron las galeras y naves de España, yendo por Capitán de las naos el Marqués de Mondéjar... y de las galeras D. Álvaro de Bazán». Santa Cruz, Crónica, p. 282.

66. Maria Luisa Madonna: «El viaje de Carlos V por Italia después de Túnez: el triunfo clásico y el plan de reconstrucción de ciudades», en Alfredo Morales (coord.): La fiesta en la Europa de Carlos V, Sociedad Estatal para la Conmemoración de los Centenarios de Felipe II y Carlos V, Madrid, 2000, pp. 119-153.

67. Checa, Carlos V. 
El estudio comparativo de ellos nos permite afirmar con mayor certeza de la existente hasta ahora el papel de Alonso de Santa Cruz y su crónica en la gestación de la serie de paños. Aunque, como hemos dicho, no se conoce documentación que los vincule directamente, sí que es cierto que existen muchos aspectos comunes, al tiempo que los diferencian de otros relatos. A un nivel muy concreto, y por lo que respecta a las imágenes de los paños, la del segundo se centra en la gran parada militar celebrada en Barcelona, a la que únicamente dedica atención preferente Santa Cruz. Igualmente ocurre con el sexto tapiz de la serie, dedicado a las escaramuzas del marqués de Alarcón y el duque de Alba en busca de provisiones. Las similitudes también se extienden a las cartelas, ya que las del tercer y sexto paño siguen de forma casi literal la prosa del cosmógrafo imperial.

No obstante, la aparente vinculación que une su texto y la imagen de los paños de Túnez trasciende de la traslación literal de fragmentos o los evidentes paralelismos narrativos. Va más allá, y parece alcanzar a la concepción general del conjunto, así como a la forma de representar los hechos y a la figura imperial. La reflexión actual acerca del «modo de representación» usado en el conjunto de tapices oscila entre la visión planteada por F. Checa, quien entiende que la apuesta por el verismo debe entenderse en el marco de la articulación del nuevo lenguaje clásico en que iba a basarse la imagen cesárea a partir de los años 40; y la visión rigurosa, científica, defendida por M. Á. de Bunes, alejada de cualquier concesión a la Antigüedad, como un hecho diferenciado dentro del amplio conjunto artístico, alegórico y «all'antica», derivado de la campaña norteafricana. En nuestra opinión no son valores contradictorios: la serie de tapices parte de una concepción clásica, pero entendida desde una perspectiva moderna e identificada con la contemporaneidad del momento en que fueron tejidos. Más que un rechazo de la Antigüedad, representan una comprensión profunda de sus principios y valores estético-ideológicos. Esta valoración del mundo clásico sería capaz de concretizarse, en el momento de articular todo el conjunto de imágenes vinculado a la «Jornada de Túnez», a partir de distintos registros formales y expresivos en función del público al que iban dirigidas. Disponer columnas partidas, personificaciones de los ríos o soldados «a la romana», de alguna manera no es más que una aproximación superficial a la Antigüedad, válido, no obstante, para su uso en las grandes entradas triunfales italianas de 1535-1536, destinadas a un público más amplio. La concepción de los tapices es distinta de la de estas entradas: su uso limitado a ceremoniales de corte hizo que estuvieran expuestos a un público limitado, elitista y, en muchos casos, de gran nivel intelectual. Debemos tener presente, además, que tanto el creador de los diseños, Vermeyen, como los Habsburgo mecenas del proyecto, provenían de un ambiente cultural nórdico en el que el seguidismo vacío y puramente formal de la formas anticuarias no se impuso sin discusión. Las propuestas de un pensador tan influyente en la corte carolina en sus primeros momentos como Erasmo de Rotterdam así lo reflejan en textos 
como su Ciceronianus. Aunque se trata de una sátira de los vicios literarios del ambiente romano, del lenguaje pomposo de aquellos a quienes nombra «ciceronianos», parte de su ideario es trasladable a la concepción general del arte: la burda copia de los antiguos es una mascarada, «Roma ya no existe, no tiene sino ruinas y escombros, huellas, vestigios de su desgracia antigua... ¿Quiénes son esas gentes que siguen soñando con la vieja Roma dueña del mundo y con su pueblo vestido de toga?».68

Vermeyen y los ideólogos de los tapices huyeron de este tipo de elementos más evidentes, pero sí que configuraron una serie de imágenes claramente vinculadas con el ideario intelectual clásico. El carácter verista de las representaciones entronca con la tradición romana de representar hechos históricos contemporáneos destinados a exaltar públicamente la gloria del soberano, como los relieves del Arco de Tito o la Columna Trajana. La voluntad narrativa y realista, de crónica, tiene mucho que ver con la recuperación de la historia como disciplina de conocimiento rigurosa, cuyas bases las habían establecido Tucidides o Tito Livio. Tras el rigor espacial y la narración casi cruenta de los hechos se vislumbran, así, los escritos de los grandes referentes de los príncipes renacentistas y, por supuesto, de Carlos V, tales como Julio César.

La amplia formación cultural y humanista de Alonso de Santa Cruz hizo de él una figura plenamente capaz de asimilar esta forma elevada de acercamiento al pensamiento y lenguajes clásicos, reflejándolo además en sus numerosos proyectos. La forma de representación general de los tapices, con su obsesiva atención geográfica en la que se llegan a incluir cartelas de orientación, la unión texto-imagen, etc., responde a planteamientos muy similares a los que expresa Santa Cruz en su memorial remitido a Carlos V el 28 de febrero de 1557. Aunque se refiere a un proyecto distinto, en unas breves líneas destila gran parte de su concepción del arte, de su función y fundamento. En él propone hacer una Historia de las Indias «agnediendo en el libro la pintura de las provincias que allí se hallasen y escribiesen, a manera de las tablas de Ptolomeo; lo cual no es pequeño provecho para la perpetuación y buena memoria de la persona de Vuestra Alteza». ${ }^{69}$ Tanto este texto como los tapices parecen responder a una ideología de la representación común, basada en la unión de geografía e historia, texto e imagen, apoyada por tanto en el verismo y la fidelidad científica. Además, como podemos ver en la referencia a Ptolomeo, esta concepción del arte vendría justificada por los prestigiosos modelos clásicos, referente indiscutible a seguir. Como colofón, la finalidad de todo ello es perpetuar la memoria del emperador, articulando unas formas artísticas de clara finalidad persuasiva y retórica, en beneficio del poder y la gloria cesárea. Así pues, parecen evidentes las convergencias, vínculos y similitudes entre

68. Erasmo De Rotterdam: El ciceroniano, ed. de Manuel Mañas Núnez, Akal. Clásicos latinos medievales y renacentistas, Madrid, 2009.

69. Carriazo, Alonso de Santa Cruz. 
los tapices y el relato de Santa Cruz, entendidos como parte fundamental e inseparable de un proyecto mayor, de un deslumbrante conjunto de productos culturales destinados a la mitificación de la imagen de Carlos V. 